\title{
Visualizing and interpreting surface displacement patterns on unstable slopes using multi-geometry satellite SAR interferometry (2D InSAR)
}

\author{
Harald Øverli Eriksen ${ }^{\mathrm{a}, \mathrm{b}, *}$, Tom Rune Lauknes ${ }^{\mathrm{a}}$, Yngvar Larsen ${ }^{\mathrm{a}}$, Geoffrey D. Corner ${ }^{\mathrm{b}}$, Steffen G. Bergh ${ }^{\mathrm{b}}$, \\ John Dehls ${ }^{c}$, Halfdan Pascal Kierulf ${ }^{\mathrm{d}}$ \\ a Norut, P.O. Box 6434, N-9294 Tromsø, Norway \\ b Department of Geosciences, UiT-The Arctic University of Norway, P.O. Box 6050 Langnes, N-9037 Tromsø, Norway \\ c Geological Survey of Norway, P.O. Box 6315 Sluppen, N-7491 Trondheim, Norway \\ d Norwegian Mapping Authority, P.O. Box 600 Sentrum, N-3507 Hønefoss, Norway
}

\section{A R T I C L E I N F O}

\section{Article history:}

Received 15 December 2015

Received in revised form 15 December 2016

Accepted 30 December 2016

Available online 5 February 2017

\begin{abstract}
A B S T R A C T
It is well known that satellite radar interferometry (InSAR) is capable of measuring surface displacement with a typical accuracy on the order of millimeters to centimeters. However, when the true deformation vector differs from the satellite line-of-sight (LOS), the sensitivity decreases and interpretation of InSAR deformation measurements becomes challenging.

By combining displacement data from extensive ascending and descending TerraSAR-X datasets collected during the summer seasons of 2009-2014, we estimate two-dimensional (2D) InSAR surface displacement. Displacement data are decomposed into vertical and west/east deformation, dip and combined deformation vector, and validated using Global Navigation Satellite System (GNSS) data. We use the decomposed dataset to visualize variations in surface velocity and direction on unstable slopes in a periglacial environment with sporadic permafrost in northern Norway. By identifying areas with uplift and subsidence, and detecting velocity changes (downslope acceleration/deceleration) and related areas of extension and compression, we are able to explain driving and controlling mechanisms and geomorphology in two rockslides and one area with solifluction landforms.
\end{abstract}

(c) 2017 Elsevier Inc. All rights reserved.

\section{Introduction}

Measurement of surface displacement gives unique insights into a variety of active processes related to slope instability, subsidence, degradation of permafrost, earthquakes and volcanic activity. Many methods have been used for mapping and monitoring ground surface displacement. These include interpretation and comparison of aerial photographs (Krainer and Mostler, 2000), photogrammetry (Kaufmann, 1998), ground-based surveys using triangulation and laser ranging (Konrad et al., 1999), differential Global Navigation Satellite System (dGNSS) (Krainer and He, 2006), terrestrial laser scanning (Bauer et al., 2003), and comparison of digital elevation models (Kääb, 2002). These techniques are restricted to provide point measurements, track features moving with high velocity, or are based on an assumption that flow is parallel to the surface.

During the last few decades, satellite-based interferometric synthetic aperture radar (InSAR) has become an important tool for mapping and monitoring a variety of displacement processes (Gabriel et al., 1989; Massonnet and Feigl, 1998). Satellite InSAR covers large

\footnotetext{
* Corresponding author at: Norut, P.O. Box 6434, N-9294 Tromsø, Norway.

E-mail address: harald.overli.eriksen@norut.no (H.Ø. Eriksen).
}

areas, with no restriction as to weather or light conditions. Depending on the revisit period of the SAR satellite, InSAR can monitor relative ground displacement on a scale of millimeters to centimeters. InSAR data have, in particular, been used for monitoring slope instability (Berardino et al., 2003; Hilley et al., 2004; Lauknes et al., 2010; Henderson et al., 2011), land subsidence related to groundwater extraction (Chaussard et al., 2014), glacier flow, volcanic activity (Massonnet et al., 1995), active layer thickness (Liu et al., 2012), rock glaciers (Liu et al., 2013) and deformation related to earthquakes (Massonnet et al., 1993; Fialko et al., 2005). The satellite InSAR technique allows us to measure surface displacement by repeatedly illuminating the ground with microwave electromagnetic energy, exploiting the phase part of the complex signal.

However, the radar is only sensitive to displacement along the satellite line-of-sight (LOS) direction. Displacement orthogonal to the LOS direction (blind plane) cannot be detected. To illustrate this, the LOS vectors for the ascending and descending satellite orbits are plotted in a west-east cross-section together with two different displacement scenarios (Fig. 1). The displacement in scenario 1 is possible to detect from both satellite orbits, though the sensitivity is best from the descending satellite orbit. In scenario 2 the displacement is parallel to the blind plane of the radar in ascending satellite orbit and cannot be measured. 


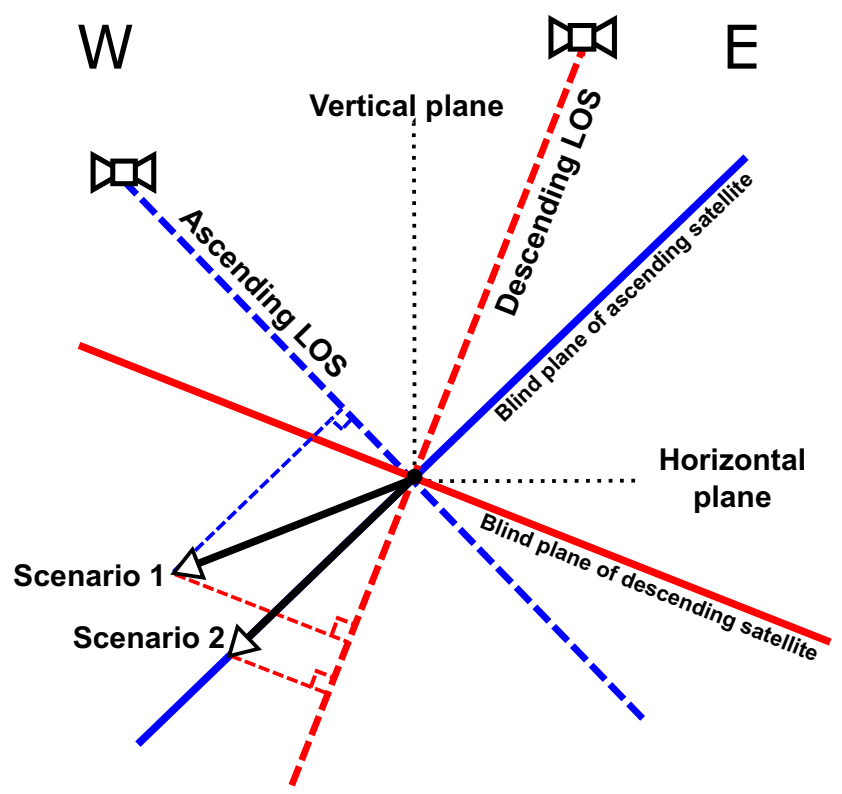

Fig. 1. West-east cross-section showing sensitivity to displacement for InSAR data in ascending and descending satellite orbits. Solid red and blue lines indicate blind planes. Arrows show direction and magnitude of two displacement scenarios having different sensitivity from ascending and descending satellite orbits.

Relating InSAR displacement maps to ongoing surface displacement processes can be difficult. A knowledge of the LOS direction for the applied satellite geometry as well as factors controlling the direction of displacement (gradient and aspect of the terrain, orientation of controlling geological structures) is required to understand how much of the true three-dimensional (3D) displacement can be observed.

However, combining InSAR displacement data from ascending and descending satellite orbits can help increase sensitivity for displacement close to the blind plane. There are a number of ways to exploit and combine several InSAR datasets (Hu et al., 2014). Some studies assume a surface-parallel displacement direction (Joughin et al., 1998; Gourmelen et al., 2007). This is not always feasible when studying features such as rockslides displaying complex displacement patterns. Others studies exploit the amplitude part (feature-tracking) of the complex radar backscatter for studying areas with displacement on the order of decimeters (Fialko et al., 2001; Funning et al., 2005; González et al., 2009; Erten et al., 2010). This is not useful for studying creeping processes with displacement on the order of centimeters per year ( $\mathrm{Hu}$ et al., 2014).

By combining InSAR displacement data from two different satellite orbits, we have produced a 2D displacement vector surface. This dataset has enhanced sensitivity to displacement in the plane spanned by the two LOS vectors (LOS-plane). This is referred to as the 2D InSAR method. It was first used to study surface deformation related to earthquakes (Fujiwara et al., 2000). Later work applied this method to studying horizontal and vertical deformations related to volcanic activity (Manzo et al., 2006), mining, ground water extraction and $\mathrm{CO}_{2}$ injection (Gourmelen et al., 2007; Rucci et al., 2011; Chaussard et al., 2014), displacement of buildings (Gernhardt and Bamler, 2012) and earthquakes (Wright et al., 2004). However, except for Fujiwara et al. (2000), no studies using the spatial variations in 2D InSAR dip and combined velocity to investigate surface displacement have been made.

In this study, we apply the 2D InSAR method in a new setting. By exploiting displacement data from overlapping areas in two high-resolution TerraSAR-X datasets acquired from ascending and descending orbits, we create maps and cross-sections showing dip angles, magnitude and spatial variation of surface displacement for rockslides and solifluction in a periglacial environment in northern Norway. The observed surface displacement is explained with reference to geological structures and landforms. For validation of the 2D InSAR method we use Global Navigation Satellite Systems (GNSS) data from the Jettan rockslide, where displacement patterns have been monitored since 2010 (Braathen et al., 2004; Henderson et al., 2008; Blikra et al., 2009; Blikra et al., 2015).

\section{Study area}

The study area is located in the municipality of Kåfjord, Troms County, northern Norway. The area includes the Nordnes Peninsula and the valleys of Kåfjorddalen and Manndalen (Fig. 2). The topography is alpine with steep mountains surrounded by fjords and valleys. The climate is subarctic, and the local permafrost limit is $600-700 \mathrm{~m}$ above sea level (a.s.l.) for the Nordnes Peninsula (Blikra and Christiansen, 2014).

The landscape has been formed and is being actively reshaped by ongoing mass-wasting processes, some controlled by diurnal and seasonal freeze-thaw cycles (Hjort et al., 2014; Eckerstorfer et al., submitted). The study area includes several active and inactive rockslides (Lauknes et al., 2010; Henderson et al., 2011; Bunkholt et al., 2013b; Hermanns et al., 2013), a high density of rock glaciers (Lilleøren \& Etzelmüller, 2011) and widespread solifluction landforms (Hjort et al., 2014).

We selected areas with active displacement to validate and show applications of the 2D InSAR method. These are: (1) the GNSS-network at the Jettan rockslide on the Nordnes Peninsula - used for validation; (2) the Gámanjunni 3 rockslide in Manndalen; (3) the Njárgavárri rockslide in Kåfjorddalen; and (4) solifluction landforms at the tip of the Nordnes Peninsula (Fig. 2). The areas are located at altitudes between about 600 and $1100 \mathrm{~m}$ a.s.l., and are thus expected to be within the regional permafrost zone.

\section{Materials and methods}

\subsection{InSAR processing}

We produced InSAR data from ascending and descending satellite orbits covering all of the localities using the Norut GSAR software (Larsen et al., 2005). We used snow-free scenes from 2009 to 2014 acquired by the TerraSAR-X radar satellite, which has a wavelength of $3.10 \mathrm{~cm}$ and a revisit period of 11 days. Single-look complex images from ascending and descending orbits were co-registrated and multilooked, $6 \times 6$ and $8 \times 6$, respectively, producing two stacks of interferograms with ground pixel sizes of approximately $12 \times 12 \mathrm{~m}$. Each stack contained approximately 160 interferograms, spanning annually from June until October (Table 1). We selected interferograms having a temporal baseline $<55$ days, which made it possible to follow high velocity displacement in the study area. We removed interferograms from early spring and late fall because of low coherence due to different surface scattering characteristics in snow-covered to snow-free scenes.

We reduced the noise-level in all the interferograms by applying a Goldstein filtering technique (Goldstein and Werner, 1998). Pixels with layover were masked out. Noisy interferograms were removed by manual quality control, and only pixels with coherence above 0.2 in $35 \%$ of the interferograms were kept for the phase unwrapping. After that, the contribution from stratified atmosphere was removed by estimating a phase delay elevation profile for each interferogram (Cavalié et al., 2007). We unwrapped all the interferograms using SNAPHU (Chen and Zebker, 2001). We also performed a manual quality control of the unwrapped interferograms, removing the ones having obvious errors.

Because persistent scatterer interferometric (PSI) processing produces sparse spatial coverage and Small Baseline Subset (SBAS) processing of individual years gave a low signal-to-noise ratio, the mean yearly velocity for each pixel for the ascending and descending datasets was 


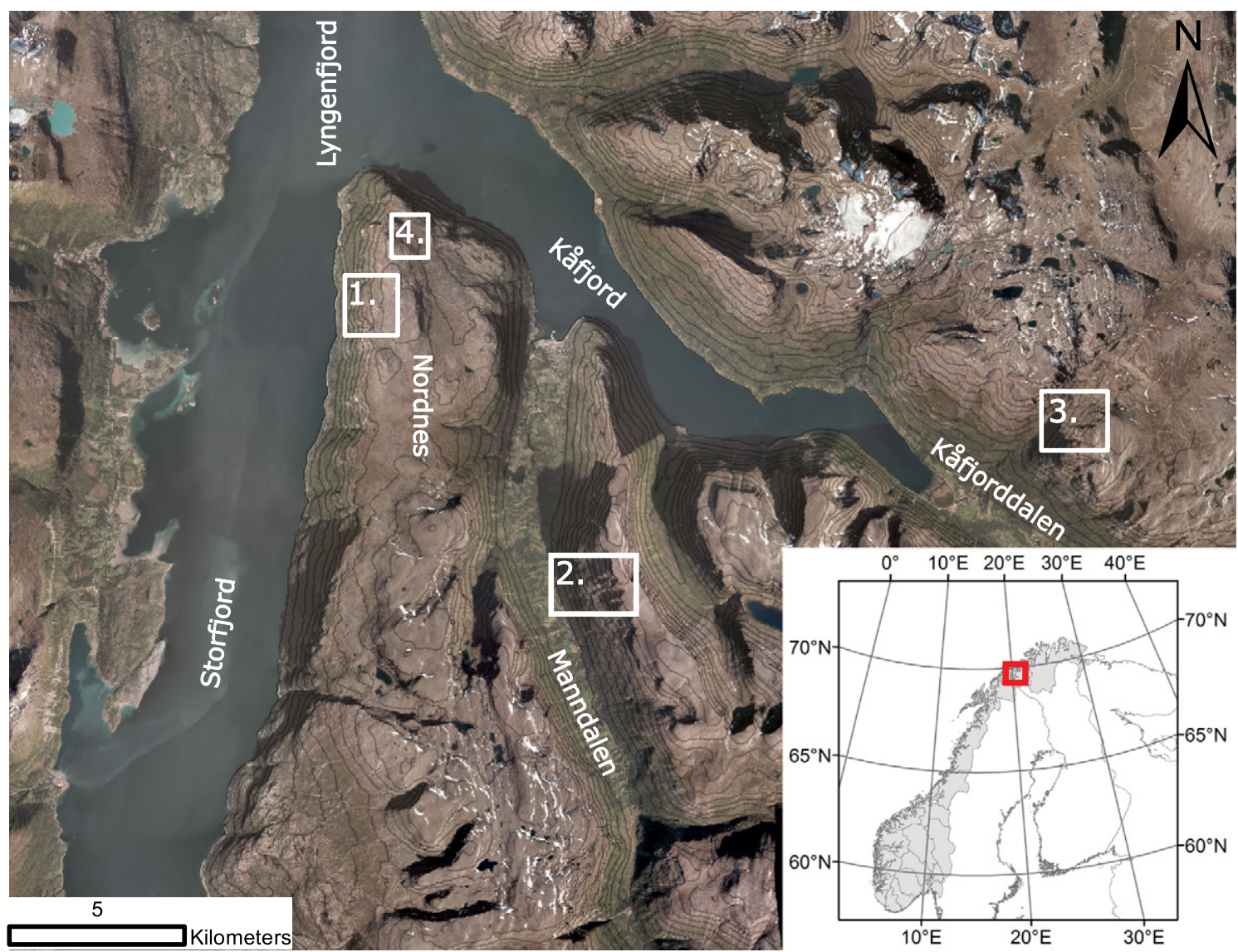

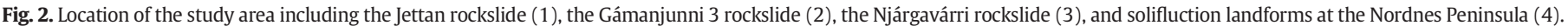
Contour interval is $100 \mathrm{~m}$.

computed by a weighted averaging (stacking) of all the interferograms from the entire time period using all interferograms simultaneously. (Lyons and Sandwell, 2003). In this way, interferograms from the snow-free season were used to give a mean yearly velocity, assuming the same velocity for the snow-free and snow-covered period. Interferogram stacking is a method that reduces the atmospheric effects on InSAR by averaging independent SAR interferograms (Peltzer et al., 2001). Averaging of independent interferograms assumes an uncorrelated tropospheric effect between interferograms $(\mathrm{N})$ and will reduce the atmospheric signal proportional to the square root of $\mathrm{N}$. We only computed interferograms spanning the period from June to September for each year, using a maximal temporal baseline of 55 days. This minimizes the risk of phase ambiguities due to fast displacement and low temporal sampling. Finally, the resulting phase was converted to

Table 1

Time interval and number of interferograms used to produce mean yearly velocity for the InSAR data from ascending and descending satellite orbits.

\begin{tabular}{llllll}
\hline Year & Geometry & $\begin{array}{l}\text { Start date } \\
\text { DD/MM }\end{array}$ & $\begin{array}{l}\text { End date } \\
\text { DD/MM }\end{array}$ & Days & $\begin{array}{l}\text { Number of } \\
\text { interferograms }\end{array}$ \\
\hline 2009 & Ascending & 16.06 & 23.09 & 100 & 23 \\
2009 & Descending & 10.06 & 28.09 & 111 & 37 \\
2010 & Ascending & 03.06 & 10.09 & 100 & 27 \\
2010 & Descending & 08.06 & 15.09 & 100 & 18 \\
2011 & Ascending & 12.06 & 30.09 & 111 & 29 \\
2011 & Descending & 17.06 & 05.10 & 111 & 40 \\
2012 & Ascending & 01.07 & 27.09 & 89 & 19 \\
2012 & Descending & 03.06 & 13.10 & 133 & 45 \\
2013 & Ascending & 07.06 & 25.09 & 112 & 35 \\
2013 & Descending & 01.06 & 30.09 & 122 & 24 \\
2014 & Ascending & 19.07 & 23.09 & 67 & 20 \\
2014 & Descending & 10.06 & 09.10 & 122 & 2 \\
\hline
\end{tabular}

velocity in millimeters per year and geocoded from radar geometry to map geometry, using a digital elevation model (DEM). LOS-vectors for the resulting ascending and descending InSAR dataset were 78/45 and 283/52 (azimuth/dip), respectively.

\subsection{Calibration and constraining input to the $2 D$ InSAR procedure}

InSAR is a relative technique, meaning that it must be calibrated to a point having a known velocity. The output for the 2D InSAR technique is sensitive to how accurate the input datasets are calibrated. Displacement of the common reference point will cause a shift in dip angles and velocities of the resulting 2D InSAR data. Therefore, we calibrated the ascending and descending InSAR datasets using a two-step routine. First, both datasets were calibrated to an initial common reference point. We used an area ( $3 \times 3$ pixels) covering the reference GNSS station (GNSS 1) outside the unstable area of the Jettan rockslide. Then we compared the calibrated InSAR datasets to the GNSS stations by projecting GNSS velocity vectors into the InSAR ascending and descending LOS directions. The mean difference between the two measuring techniques ( $\triangle$ Asc and $\triangle$ Desc), based on data from all GNSS stations, was used to re-calibrate the ascending and descending InSAR datasets. By constraining the input to the 2D InSAR procedure to the GNSS-network, we ensure a more reliable outcome. After processing and a twostep calibration, the TerraSAR-X ascending and descending datasets were used as input to the 2D InSAR algorithm.

\subsection{Combination of ascending and descending datasets (2D InSAR)}

Combined annual velocity vector $\mathrm{T}(\mathrm{mm} / \mathrm{yr}$ ) was calculated using the ascending LOS unit vector $u_{\mathrm{a}}$, its unit normal vector in the LOS- 
plane $\underline{u}_{a}^{\perp}$, the angle $\alpha$ between ascending and descending LOS vectors and the estimated velocities from ascending and descending satellite orbits $\left(\mathrm{d}_{\mathrm{a}}\right.$ and $\left.\mathrm{d}_{\mathrm{d}}(\mathrm{mm} / \mathrm{yr})\right)$ solving the geometrical problem in (Fig. 3 ) and equation 1 and 2 :

$$
\begin{aligned}
& \underline{\mathrm{T}}=\mathrm{d}_{\mathrm{a}} \underline{u}_{\mathrm{a}}+\underline{u}_{a}^{\perp}(1) \\
& \underline{\mathrm{T}}=\mathrm{d}_{\mathrm{a}} \underline{u}_{\mathrm{a}}+\frac{\mathrm{d}_{\mathrm{d}}-\mathrm{d}_{\mathrm{a}} \cos \alpha}{\sin \alpha} \underline{u}_{a}^{\perp}(2)
\end{aligned}
$$

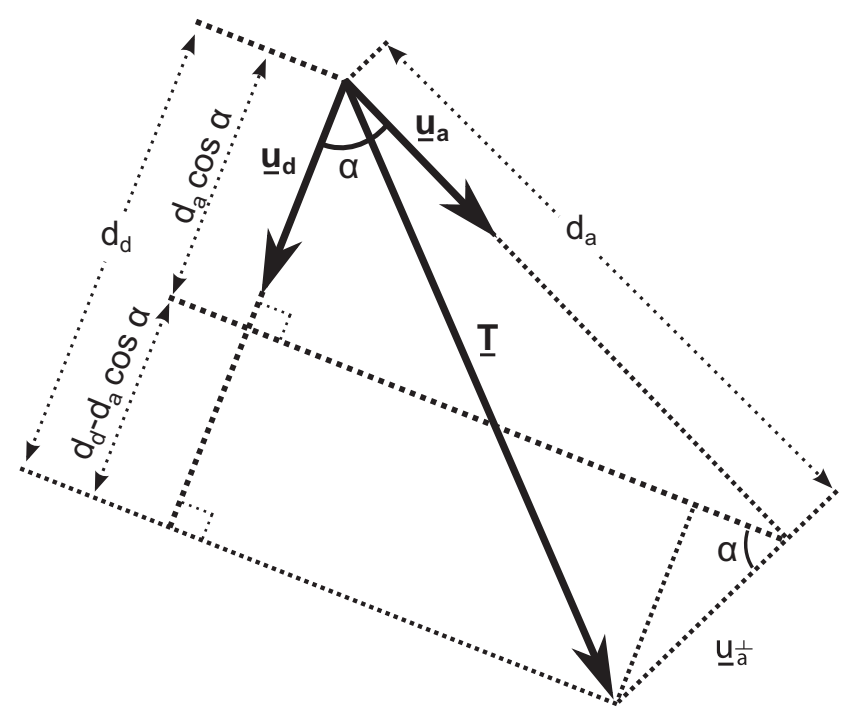

Fig. 3. Geometric problem raised in order to find combined annual velocity vector $\mathrm{T}$, given two non-parallel LOS measurements.

Vector T gives velocity and dip of displacement for each pixel that is common to both the ascending and descending datasets. The orientation of the LOS-plane is close to vertical, striking close to westeast (Fig. 4a). Thus, vector T contains the projection of the true surface velocity in this plane. Note that in terrains having a large velocity component towards north or south, this component will be underestimated since it is perpendicular to the LOS-plane. To simplify, we calculated the projection of vector $\mathrm{T}$ in the west-east, up-down plane; vector TwEP. From $T_{\text {WEP }}$ we calculated horizontal $(h)$ and vertical (v) yearly velocities, and then dip of $\mathrm{T}_{\mathrm{WEP}}(\Theta)$ based on $\mathrm{h}$ and $\mathrm{v}$ (Fig. 4b). The angle $\Theta$ will be referred to as the dip of displacement, and is represented by a color palette divided into sectors of $15^{\circ}$ (Fig. 4c). We use positive dip for areas moving down, negative for areas moving up. Dip values are given as $\mathrm{E}$ or $\mathrm{W}$, indicating displacement towards east or west. In a terrain with varying topography, horizontal and vertical components from 2D InSAR can be difficult to interpret. It is easier to relate and compare variations in 2D InSAR dip in cross-sections that spans geological- and geomorphological elements, than to evaluate variations in both the 2D InSAR horizontal and vertical component. We did this for all sites. Moreover, for the Gámanjunni 3 rockslide, we calculated the difference between 2D InSAR dip and the slope gradient to identify areas where displacement is moving out of the slope (uplift) or into the slope (subsidence).

An important aspect of the 2D InSAR technique is that it is constrained by the input datasets' sensitivity to displacement. For datasets captured by earth observing satellites in near-polar orbits, surface processes having a large horizontal deformation component in the $\mathrm{N}-\mathrm{S}$ direction will result in dip of displacement converging towards vertical down $\left(90^{\circ}\right)$ or vertical up $\left(-90^{\circ}\right)$, plus an underestimation of magnitude values.

\subsection{Geological and morphological interpretation}

For the geological and geomorphological interpretation, we used a DEM $(10 \times 10 \mathrm{~m}$ resolution, http://data.kartverket.no/download/ content/digital-terrengmodell-10-m-utm-33), Light Detection and Ranging (LIDAR) data from $2014(1 \times 1 \mathrm{~m}$ resolution) and orthophotos Finnmark-Troms $2006(0.5 \times 0.5 \mathrm{~m}$ resolution $)$ and Troms 2011 ( $1 \times 1 \mathrm{~m}$ resolution, http://www.norgeibilder.no/), all supplied by the Norwegian Mapping Authority. In addition, for the Gámanjunni 3 rockslide, we used an orthophoto $(0.1 \times 0.1 \mathrm{~m}$ resolution $)$ and a DEM $(0.25 \times 0.25 \mathrm{~m})$, both from 2011, provided by Geological Survey of Norway (NGU). We used DEM-data to produce cross-sections, and DEM and LiDAR data to produce slope maps. The slope maps are used in two ways: (1) for interpretation of morphology (back scarps, slide scarps, slide fronts, lateral borders); and (2) for comparing 2D InSAR dip of displacement to slope gradient in cross-sections for finding areas having subsidence and uplift.

Synthesizing different datasets (e.g. GNSS, 2D InSAR, geological structures and geomorphological elements) in map view and cross-section enable discussion of the processes responsible for the displacement both spatially and underground. For all localities, we selected cross-sections based on the 2D InSAR LOS-plane orientation and geological structures and landforms. 2D InSAR data was plotted as vectors on the terrain surface to identify and as a basis for discussing subtle spatial variations in ongoing displacement processes. Where the orientations of the crosssections differ from the LOS-plane, the combined annual velocity vector ( $\mathrm{T}$ ) has been projected into the cross-section before plotted on the terrain surface.

\section{Results}

Before presenting the results from each locality, we validate the use of the 2D InSAR method by comparing InSAR derived displacement vectors with GNSS derived vectors from six permanent GNSS-stations located at the Jettan rockslide (Fig. 5).

\subsection{Validation of InSAR with GNSS data}

The Jettan rockslide extends almost from sea level to $800 \mathrm{~m}$ a.s.l., with parts of the active deforming area $\left(\sim 5-6 \mathrm{Mm}^{3}\right)$ moving $>50 \mathrm{~mm} / \mathrm{yr}$ (Blikra et al., 2015) (Fig. 5). The rockslide has been classified as an unstable, complex rockslide/field area (Braathen et al., 2004), controlled by permafrost (Blikra and Christiansen, 2014).

From 2D InSAR data, three areas showing particularly high rates of movement are identified in the unstable upper part of the slide: (1) a northern; (2) a southern; and (3) an upper area, all having different displacement patterns (Fig. 6). The northern area (1) has a terrace-slopeterrace topography and the highest velocity in the Jettan rockslide (Fig. 6a). We observe a heterogeneous displacement pattern, with dip of displacement varying between down-slope, out-of-slope and intoslope. This may indicate that displacement is controlled by a complex fault geometry at depth, including several stepped and discontinuous fault planes. Moreover, the varying dip of displacement, indicated by $2 \mathrm{D}$ InSAR data, show a chaotic displacement pattern, rotation of fault blocks, and varying zones of compression and extension (Fig. 6b), substantiating work by Braathen et al. (2004); Nordvik et al. (2010); Skrede (2013); Blikra et al. (2015). The southern (2) and upper (3) areas show different displacement patterns separated by the main active fracture. From 2D InSAR data, the southern (2) area has a steeper dip and shows a homogeneous displacement pattern, indicating one or more continuous fault planes at depth controlling masses moving as one unit. The upper area (3) has been interpreted by Blikra and Christiansen (2014) to be a rock glacier with most of the original bedrock structures still preserved. 2D InSAR displacement patterns support this theory suggesting a flowing motion out onto the bench formation below, controlled by the sub-horizontal foliation.

For validation of 2D InSAR displacement patterns, we used GNSS data from six stations at the Jettan rockslide, maintained by the Norwegian Water Resources and Energy Directorate (NVE). 

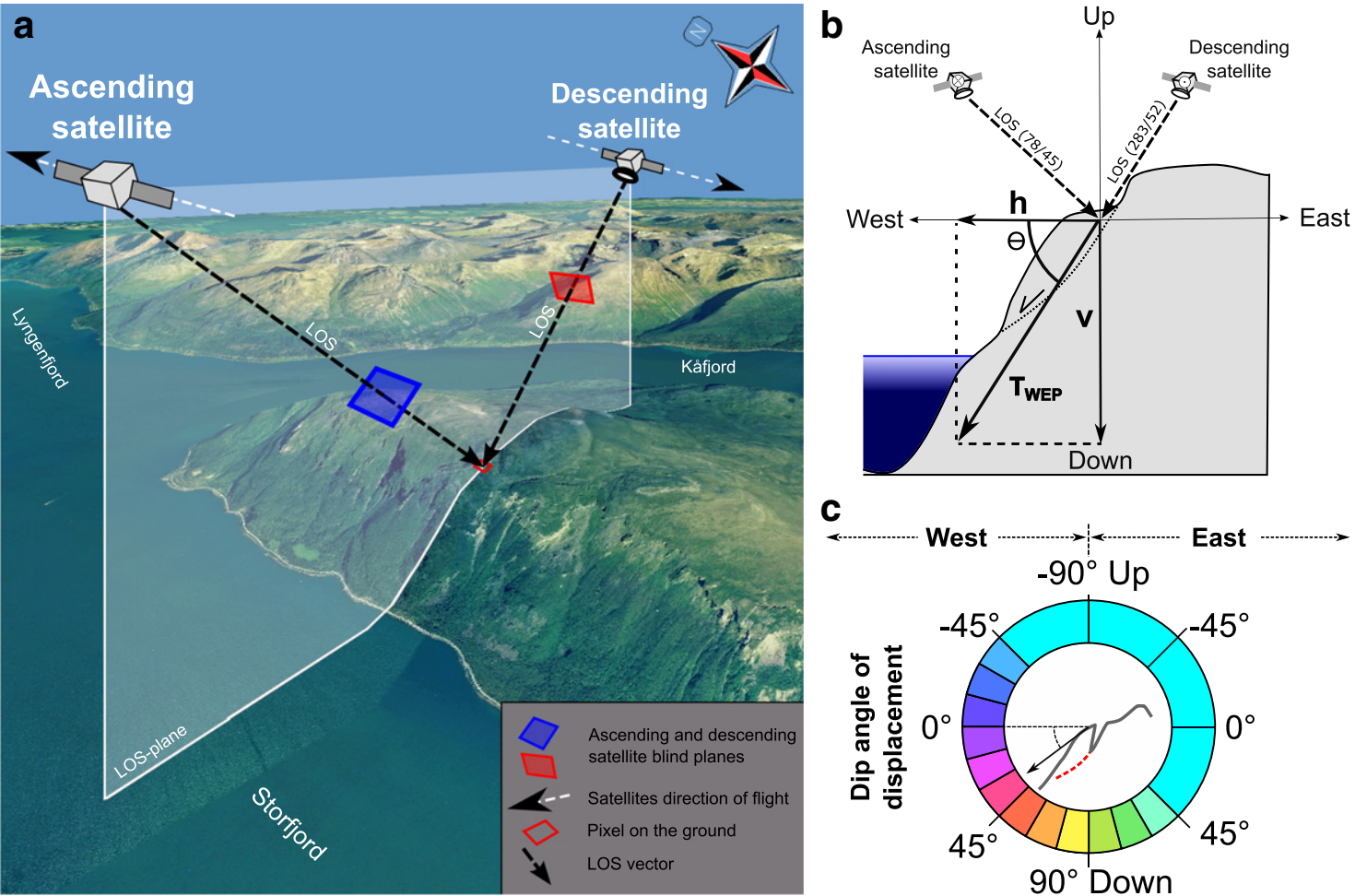

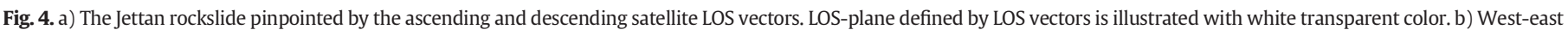

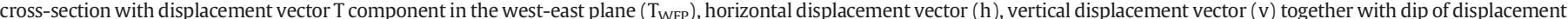
$(\Theta)$. LOS direction is given in azimuth and dip. c) Color convention used to describe dip of displacement in map view.

The GNSS data were analyzed using the geodetic GNSS software GAMIT/GLOBK. To ensure a long-term, stable reference frame, measurements from the Jettan stations were combined with results from the Norwegian Permanent GNSS network (Kierulf et al., 2014). It is well known that GNSS time-series have a more complex noise structure than only white noise (Williams, 2003). This fact has little consequence for the velocity estimates, but has significant impact on the estimated velocity rate uncertainties. We have used a combination of white noise and power law noise, where we also estimate the spectral index. The velocities, spectral index and uncertainties are estimated using the software Cheetah (Bos et al., 2008). Some of the Jettan GNSS stations show large inter and intra annual variations. This is also seen in other observations (Blikra and Christiansen, 2014). To ensure a consistent comparison of the input to the 2D InSAR procedure, InSAR data captured in ascending $\left(\mathrm{d}_{\mathrm{a}}\right)$ and descending $\left(\mathrm{d}_{\mathrm{d}}\right)$ LOS direction and GNSS data, we computed the mean yearly velocity vectors for each GNSS-station based on data from the same time interval as covered by the interferograms

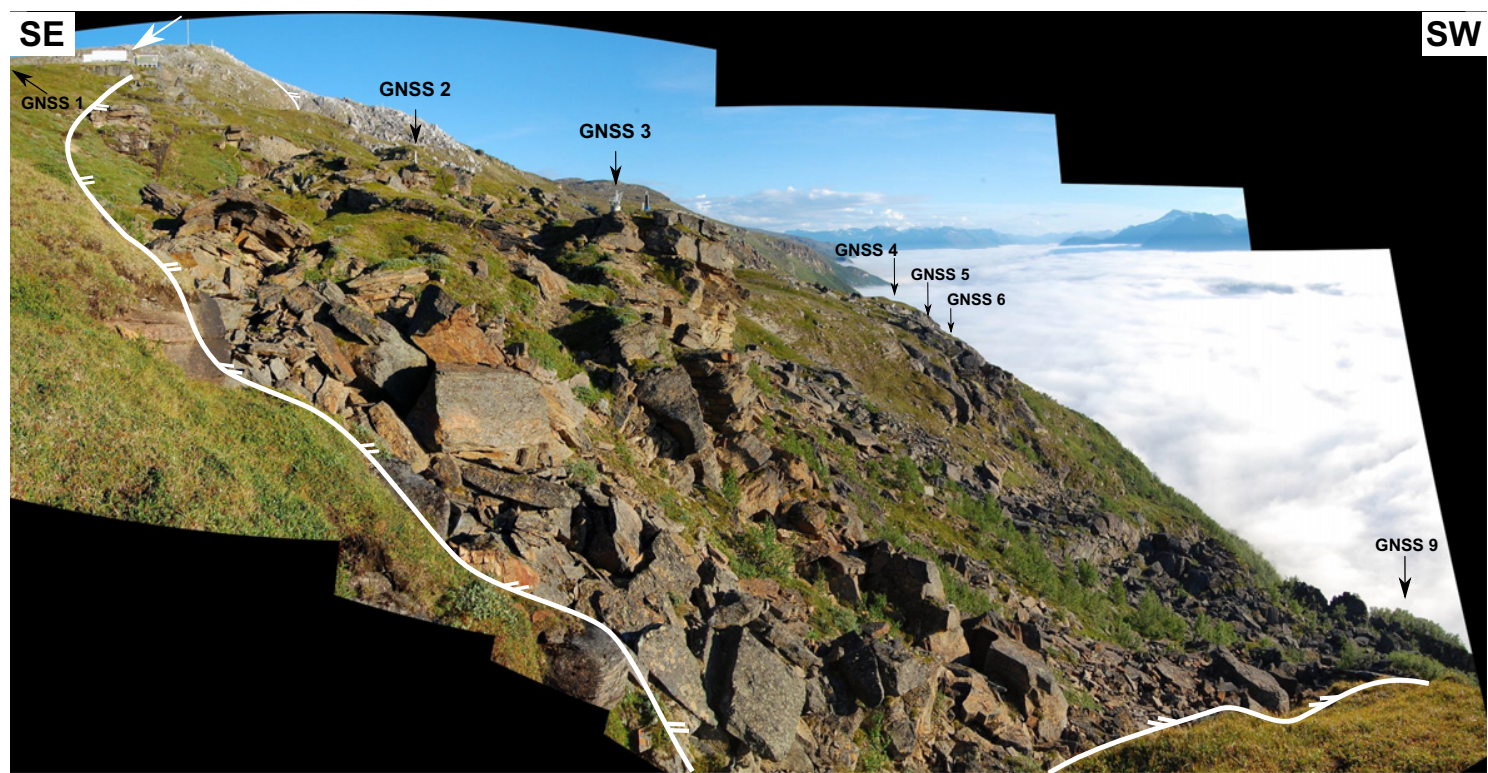

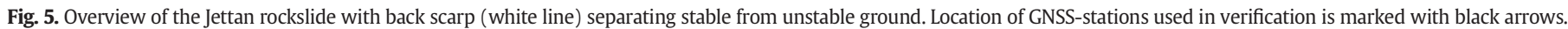
Note the white barrack ( $~ 8 \mathrm{~m}$ long) marked with a white arrow in the upper left corner for scale. 


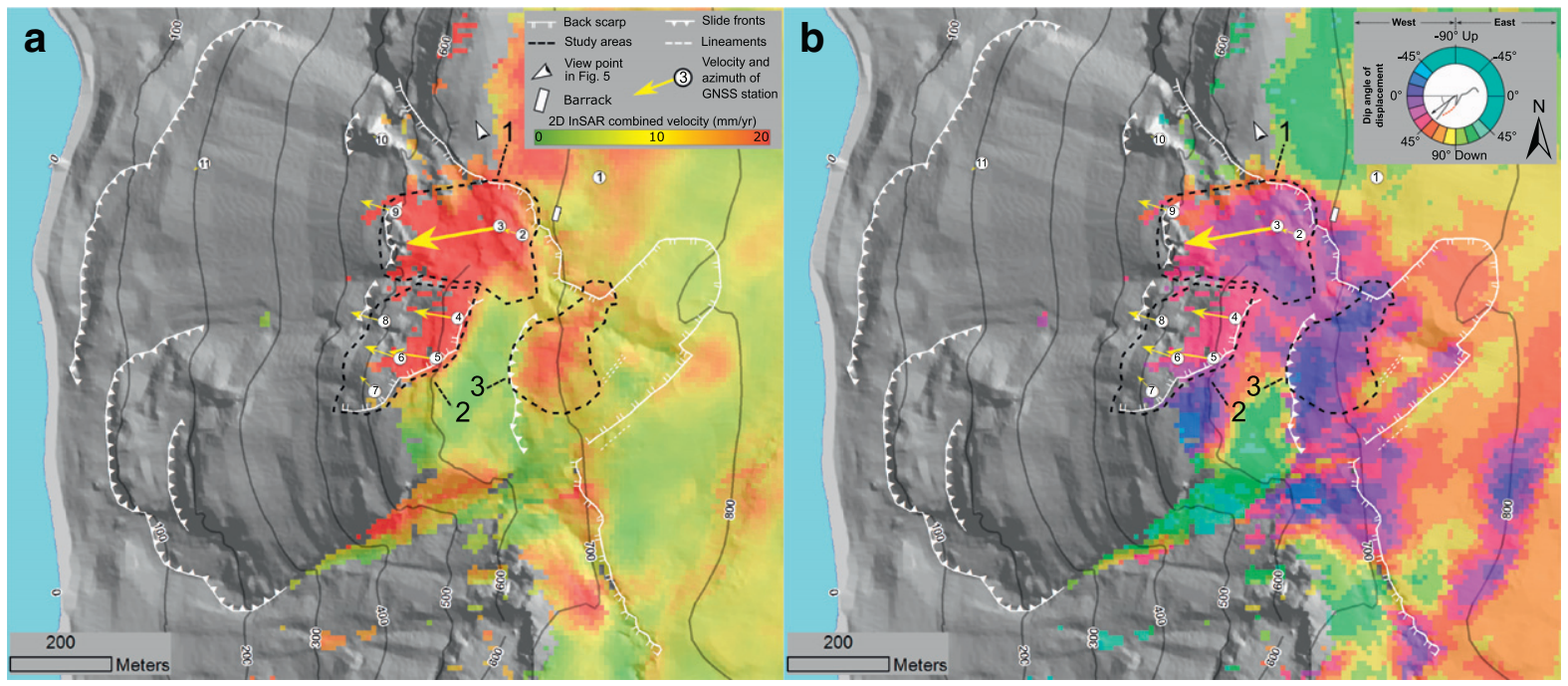

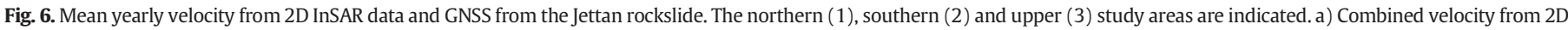
InSAR data. b) 2D InSAR dip of displacement. GNSS stations are numbered as referred in the text.

(Table 1). GNSS-vectors were projected into the InSAR ascending and descending LOS direction, with a standard deviation of 0.03 and $0.53 \mathrm{~mm} / \mathrm{yr}$ (Table 2). For the ascending and descending InSAR data $\left(d_{a}, d_{d}\right)$, we assume a conservative standard deviation of $5 \mathrm{~mm}$ per interferogram due to the atmosphere. By using Eq. (11) from Emardson et al. (2003), with 153 interferograms and a maximum temporal baseline of 55 days, we estimate the standard deviation of the retrieved mean velocity to $2.7 \mathrm{~mm} / \mathrm{yr}$. The difference between the two measuring techniques, $\Delta$ Asc and $\Delta$ Desc, has a mean of 6.1 and $5.9 \mathrm{~mm} / \mathrm{yr}$, respectively. Compared with the rates based on the complete GNSS coordinate time series, only a few rate estimates deviate more than the rate uncertainties. Data from GNSS station 3 show large intra and inter annual variations and is only station where rate estimates based on the restricted time intervals (also covered by the interferograms) deviate from the complete time series by several mm/yr. 2D InSAR compared to the GNSS data show good agreement for the horizontal and combined displacement and some deviation in the vertical component and dip of displacement (Fig. 7).

Some clarifications regarding the difference between the GNSS and 2D InSAR data is needed. First, velocity from GNSS data is calculated based on a point measurement (block), while the 2D InSAR data give a mean velocity calculated from all natural reflectors inside an area on the ground. This difference (representation error) is to be expected in an area having complex displacement patterns like Jettan (Fig. 5). An example is shown by GNSS 3, the station with the highest velocity, which is underestimated with regard to horizontal and 2D InSAR combined velocity (Fig. 7a, c). This means that the contribution from all natural reflectors in the pixel containing GNSS 3 gives a lower InSAR velocity than the point measurement registered by GNSS 3. A contributing factor to deviation between mean yearly velocities from 2D InSAR and lower altitude GNSS stations, is their vicinity to lower elevated areas along the slope, affected by foreshortening, which reduces the effective resolution. Moreover, some of the deviation could be explained by the constellation of GNSS-satellites, which result in lower accuracy of the vertical component at higher latitudes (Langley, 1999). Lastly, the mean direction of displacement for the GNSS stations (279/ 36 ) is close to the blind plane of the ascending InSAR geometry. Thus, highly reduced sensitivity to displacement is expected for the ascending InSAR geometry. The GNSS dip compared to 2D InSAR dip have a mean deviation from GNSS dip (mean error) of 11 degrees (Fig. 7d). With the above discussed deviations in mind, we find a low Pearson product-moment correlation coefficient (PPC), indicating low linear correlation between GNSS and 2D InSAR dip data. We think the comparison are a result of measuring techniques used (point vs. area) in an area with a complex displacement pattern, and consider the 2D InSAR dip data to be acceptable.

It should be added that the stacking algorithm relies on the assumption that by averaging all interferograms, the atmospheric contribution will cancel out. This is most likely not the case everywhere and local variations should be expected. This is especially important when working with 2D InSAR data covering areas with large differences in elevation, and with a stratified atmosphere.

Table 2

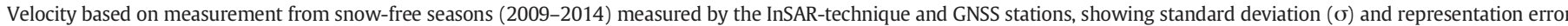
$(\Delta$ Asc, $\Delta$ Desc), all in millimetres per year in satellite line-of-sight.

\begin{tabular}{|c|c|c|c|c|c|c|c|c|c|c|}
\hline \multirow[b]{2}{*}{ GNSS station } & \multicolumn{5}{|c|}{ Data projected into TSX-ascending LOS } & \multicolumn{5}{|c|}{ Data projected into TSX-descending LOS } \\
\hline & $\operatorname{InSAR}\left(\mathrm{d}_{\mathrm{a}}\right)$ & $\sigma, \operatorname{InSAR}\left(\mathrm{d}_{\mathrm{a}}\right)$ & GNSS & $\sigma$, GNSS & $\Delta$ Asc & $\operatorname{InSAR}\left(\mathrm{d}_{\mathrm{d}}\right)$ & $\sigma, \operatorname{InSAR}\left(\mathrm{d}_{\mathrm{d}}\right)$ & GNSS & $\sigma$, GNSS & $\Delta$ Desc \\
\hline 2 & 5.2 & 2.7 & 2.6 & 0.1 & 2.6 & -18.1 & 2.7 & -6.8 & 0.2 & 11.3 \\
\hline 3 & 5.2 & 2.7 & 23.9 & -0.8 & 18.7 & -33.6 & 2.7 & -39.6 & 0.9 & 6.0 \\
\hline 4 & 0.9 & 2.7 & 1.0 & 0.0 & 0.1 & -21.7 & 2.7 & -18.3 & 0.4 & 3.4 \\
\hline 5 & 4.0 & 2.7 & -3.0 & 0.4 & 7.0 & -20.6 & 2.7 & -20.6 & 0.7 & 0.0 \\
\hline 6 & 4.5 & 2.7 & -3.5 & 0.3 & 8.0 & -22.4 & 2.7 & -17.2 & 0.6 & 5.3 \\
\hline 9 & 0.6 & 2.7 & 0.9 & 0.1 & 0.3 & -24.2 & 2.7 & -14.8 & 0.3 & 9.5 \\
\hline Mean & & & & 0.03 & 6.1 & & & & 0.53 & 5.9 \\
\hline
\end{tabular}


a.

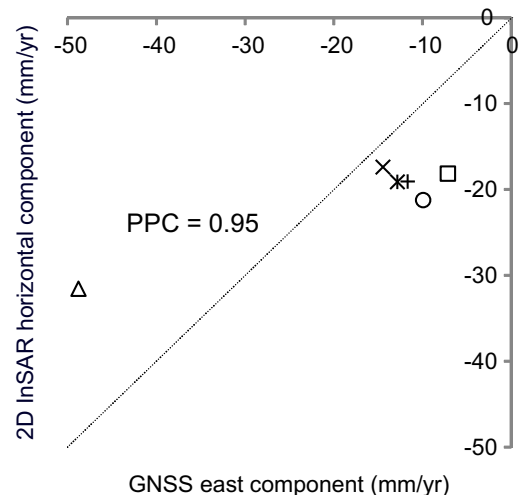

C.

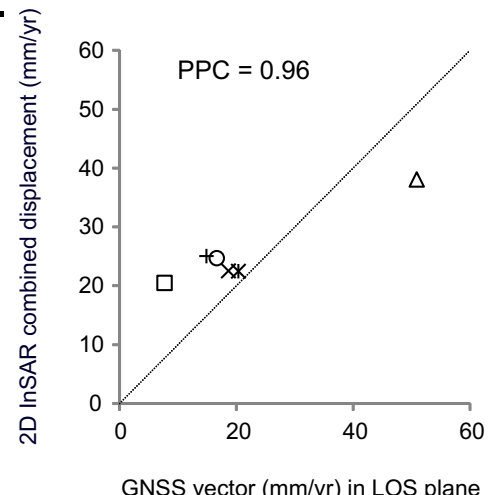

b.

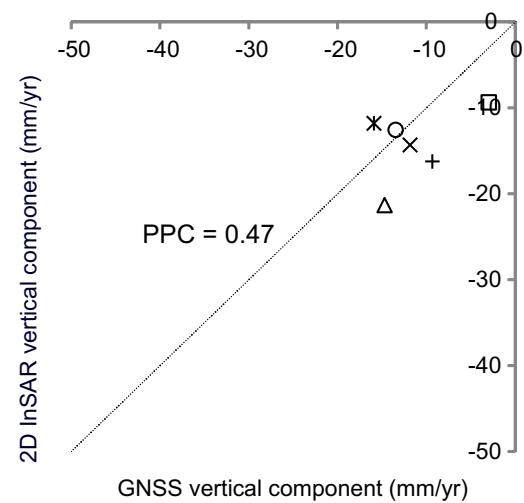

d.

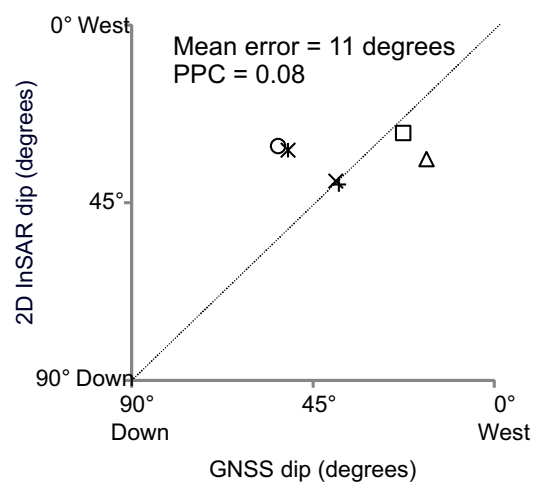

$\square$ GNSS $2 \Delta$ GNSS $3 \times$ GNSS 4

* GNSS 5 O GNSS 6 + GNSS 9

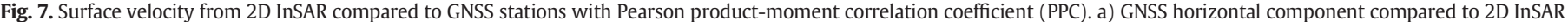

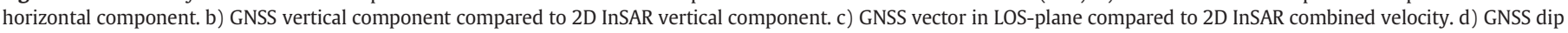
compared to 2D InSAR dip.

To summarize, the comparison of 2D InSAR and GNSS data show that 2D InSAR horizontal and combined velocity agree better with the GNSS data than the vertical 2D InSAR data. The results achieved using the 2D InSAR method are considered as reliable for interpretation of displacement patterns.

\subsection{Gámanjunni 3 rockslide}

Gámanjunni 3 is located on the east side of Manndalen and is one of several actively deforming rockslides in this area (Henderson et al., 2011; Bunkholt et al., 2013a; Böhme et al., 2016) (Fig. 2). It is located on a steep west-dipping valley slope and ranges in elevation from ca. 600 to $1220 \mathrm{~m}$ a.s.l., from toe to back scarp (Fig. 8). The average gradient is $\sim 33^{\circ}$ from the valley bottom to the back scarp. The bedrock is mainly fractured along two steeply dipping fracture sets and the foliation is sub-horizontal (metamorphic planar sheeting) (Böhme et al., 2016).

Gámanjunni 3 can be defined as a complex field rockslide (Braathen et al., 2004) comprised of an undulating slope containing steep slide scarps, benches, ridges and distinct slide front formed by ongoing sliding, block rotation and direct fall. The upper part consists of a $300 \times 200 \mathrm{~m}$ wedge-shaped block controlled by two back scarps, that has moved $\sim 150 \mathrm{~m}$ downslope with a dip of $45^{\circ}$ (Böhme et al., 2016).

In the $2 \mathrm{D}$ InSAR combined velocity data, the active deforming area is well delimited from the surroundings, with velocities above $60 \mathrm{~mm} / \mathrm{yr}$
(Fig. 9a). Dip of displacement is steeper in the upper part of the rockslide than in the lower part (Fig. 9b). Combined velocities show increasing values from the top to the middle part $(\sim 600 \mathrm{~m})$, and a decrease from the middle part to the toe (Fig. 10a). We observe steeper dip of displacement from the top to the middle part, followed by shallower dip from the middle part to the toe (Fig. 10b).

From the variations in 2D InSAR combined velocity and dip of displacement, we identify zones of downslope acceleration and deceleration (velocity change) that may possibly be related to an active stress regime with extension and compression (Fig. 10c). We have also compared dip of displacement to slope gradient along the cross-section $A-A^{\prime}$ in order to identify areas where the surface is uplifting or subsiding (Fig. 10d). We see from this that parts of the rockslide are subsiding in the upper parts and uplifted in the lower parts, with a pivot point in the middle $(\sim 400 \mathrm{~m})$. These relationships show a clear overlap between areas with uplift and subsidence and outcropping compressional (thrust) faults and extensional (normal) faults (Fig. 10).

From the data, we propose a geological (slope process) model for the Gámanjunni 3 rockslide (Fig. 10e). In the upper- to the middle-part of the rockslide, subsidence, slightly increasing velocity and successively steeper dip of displacement, indicates a stress regime with ongoing extension and sliding on normal faults. From the middle part towards the toe, shallower dip of displacement and decreasing velocities suggest a 


\section{NW}

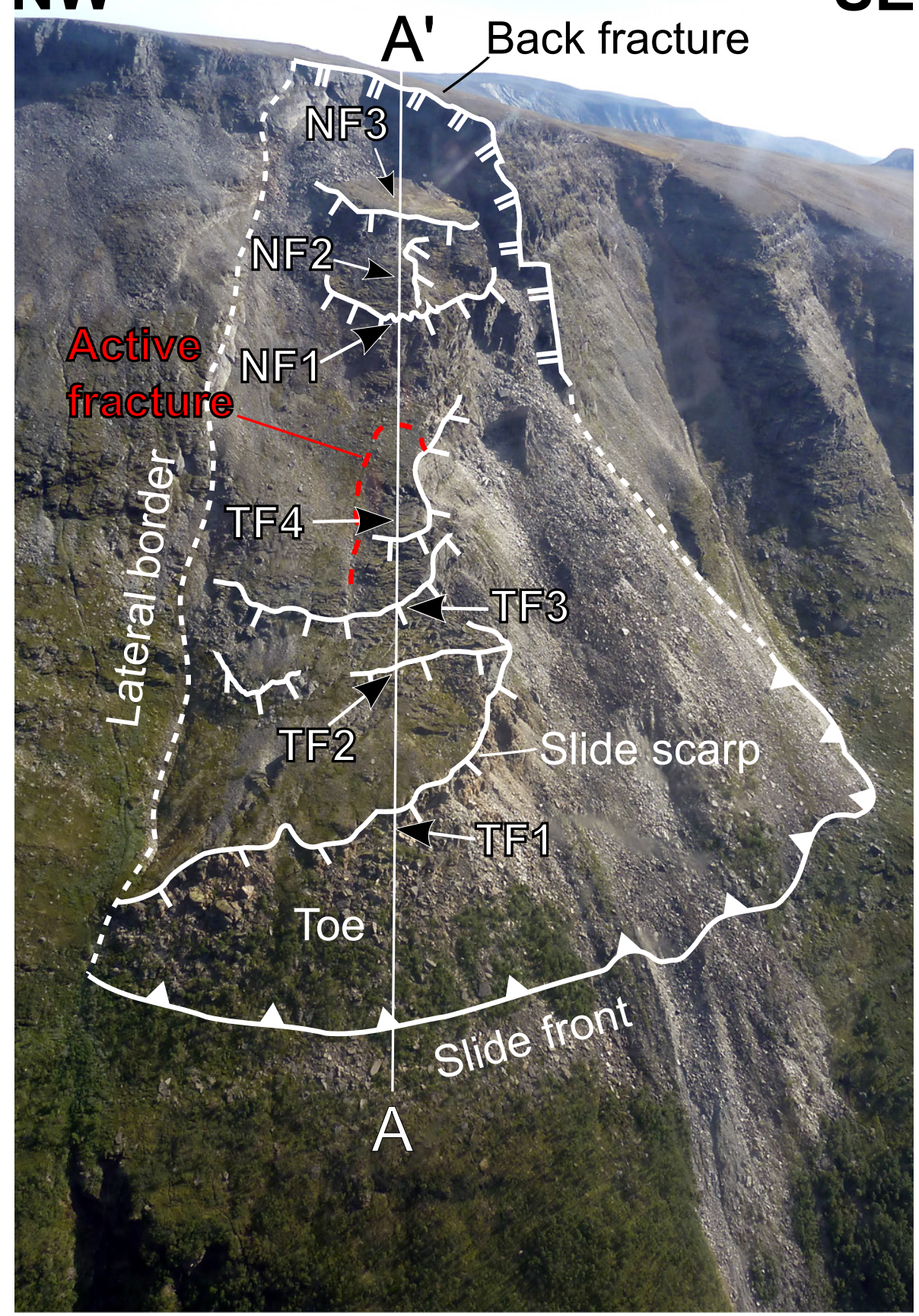

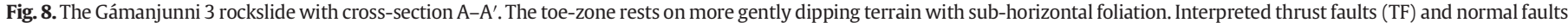
(NF) marked with arrows. (Photo courtesy Geological Survey of Norway).

change towards a compressional stress regime with increased frictional resistance, coinciding with more gently dipping terrain.

The 2D InSAR data with distinct offsets along the Gámanjunni 3 cross-section $\mathrm{A}-\mathrm{A}^{\prime}$, also reveal variations on a smaller scale that can be interpreted as being due to uplift along thrust faults (TF) and subsidence by normal faulting (NF) (arrows in Fig. 10a, b). This is supported in the rockslide toe by a stepped pattern in combined velocity and dip of displacement values, that correspond well with internal observed slide scarps in the field (arrows TF1 to TF4 in Fig. 10a, b). These scarps may be the surface signature of outcropping thrust faults, with repeated imbricated slide blocks (marked with gray stippled lines in Fig. 10d, e) thrusted over each other, producing large boulders in front (Fig. 10e). In the upper part of the rockslide, we identify increasing velocity (Fig. 10a) and discrete steps in the dip of displacement (arrows NF1 to NF3 in Fig. 10a, b), and some of these steps are observed as slide scarps in the field. We interpret these steps as being due to active normal faulting of internal slide blocks.

As discussed in Section 3.3, caution is required when interpreting 2D InSAR data in areas having large displacement components in a N-S direction (orthogonal to the LOS-plane). Overestimation of dip of displacement (too steep) and underestimation of velocity can be expected. Active fractures observed in the field as ruptured soil/ 

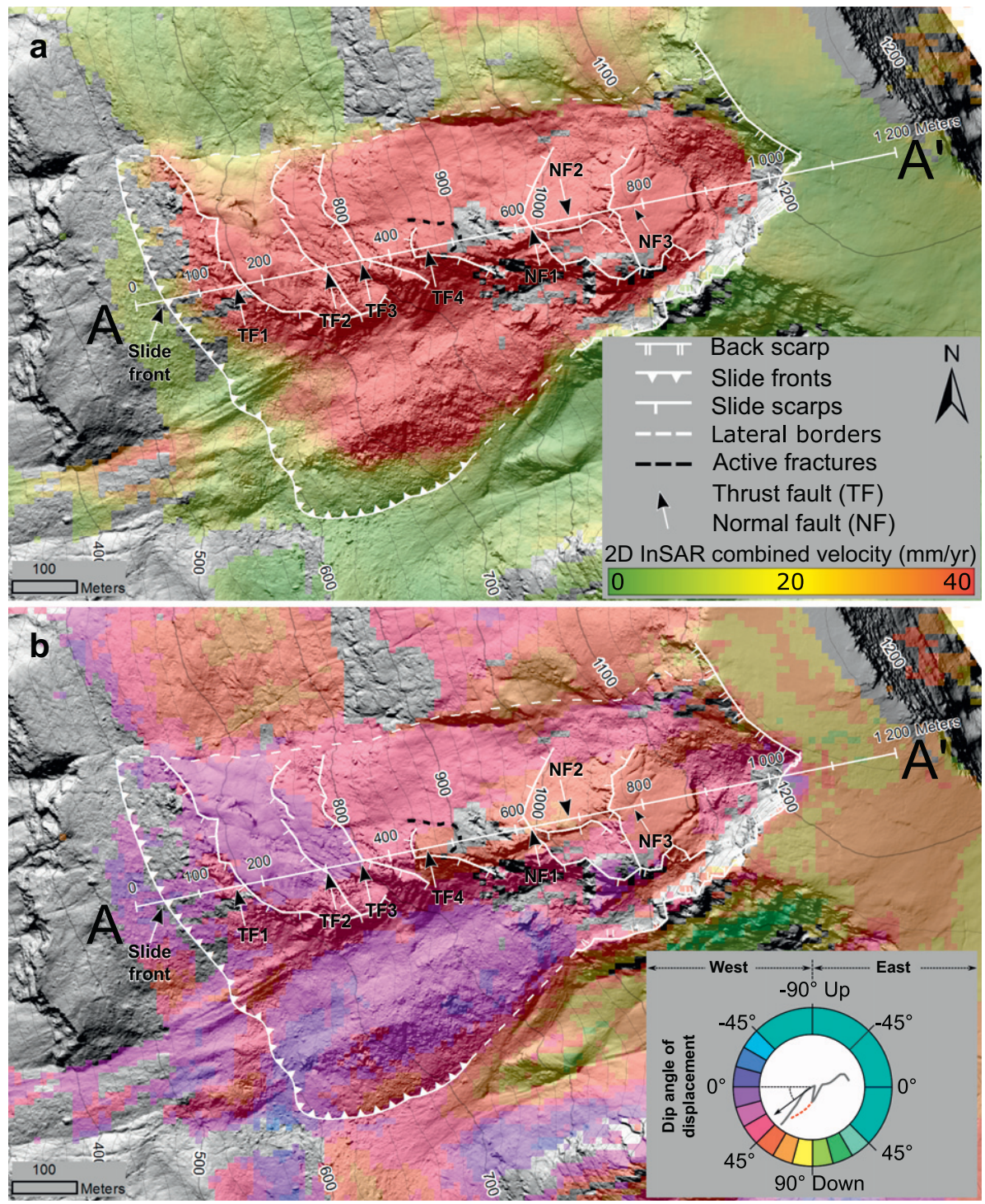

Fig. 9. Gámanjunni 3 rockslide showing 2D InSAR data and morphological elements. a) Combined velocity. b) Dip of displacement.

vegetation delimiting the area north of TF4, is one example of this (Figs. $9 \mathrm{a}, \mathrm{b}$ and $10 \mathrm{a}, \mathrm{b}, \mathrm{d}, \mathrm{e})$.

Even though we avoided interferograms from early spring and late fall in order to reduce the influence of the seasonal freezethaw cycle in the active layer, we see displacement almost vertically down in the upper part of cross-section A-A' ( 1000-1200 m). This displacement is probably related to summer thaw subsidence. If we assume the same seasonal displacement everywhere, the 2D InSAR mean yearly vertical velocity is overestimated and the dip of displacement is too steep. Although this effect could be avoided using interannual interferograms, we have used a short baseline (55 days) in order to avoid unwrapping problems in the high-velocity areas. Furthermore, we consider this influence from summer thaw to be most prominent in the upper parts of the cross-section due to a shorter summer season there.

Böhme et al. (2016) used kinematic stability tests to determine that the most likely movement direction of Gámanjunni 3 is towards WSW $\left(253^{\circ}\right)$, dipping $\sim 45^{\circ}$. Their results are supported by GNSS data from 2011 to 2014. Our results show a good match between dip of displacement estimated by 2D InSAR data from the upper part of the rockslide and the most probable sliding direction found by Böhme et al. (2016). When the movement direction of Böhme et al. (2016) is projected into the $\mathrm{A}-\mathrm{A}^{\prime}$ cross-section, it has a dip of $56^{\circ}$ towards $\mathrm{W}$ (see red dot and arrow in Fig. 10b, e).

Based on our field observations and variations in velocity, dip of displacement and stress regime from 2D InSAR data along cross-section A$\mathrm{A}^{\prime}$, we suggest a geological model connecting ongoing surface displacement at the Gámanjunni 3 rockslide to faults at depth. We suggest a stress regime with overall downslope acceleration and extension in the upper part, and compression and deceleration in the lower part. The moving masses pushing from behind are being decelerated in the toe-zone along sub-horizontal thrust planes (Fig. 11).

\subsection{Njárgavárri rockslide}

The mountain of Njárgavárri comprises a major rockslide covering an area of $640,000 \mathrm{~m}^{2}$ (Fig. 12). The unstable and deforming area is located in a side valley to Kåfjorddalen (location 3 in Fig. 2) at an altitude of 540 to $1100 \mathrm{~m}$ a.s.l. The upper parts are located above the regional permafrost limit (800-1000 $\mathrm{m}$ a.s.l.). The mean gradient of the rockslide 


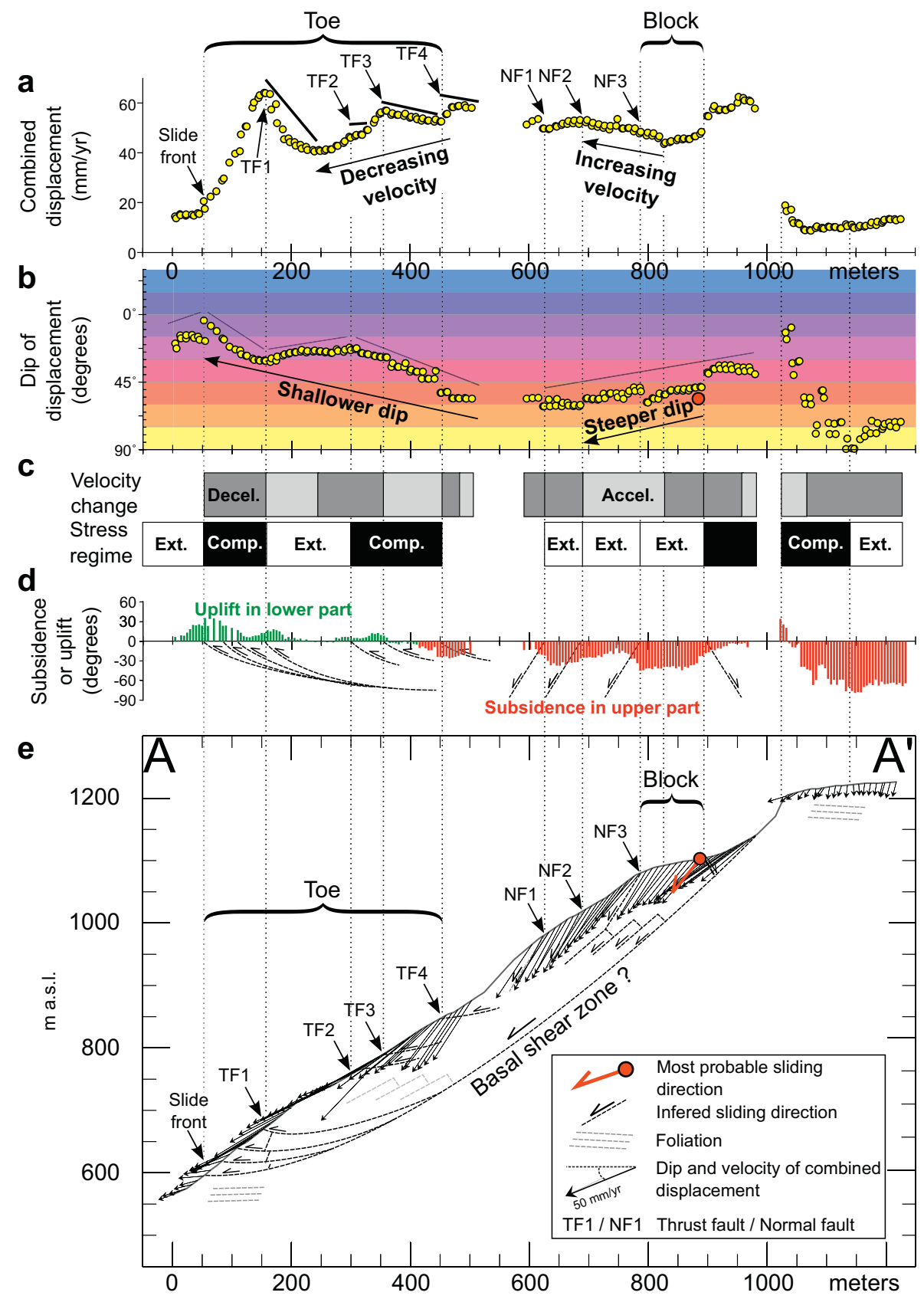

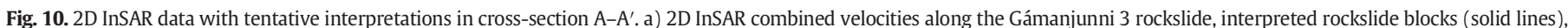

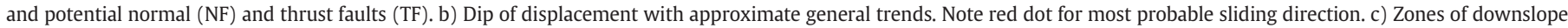

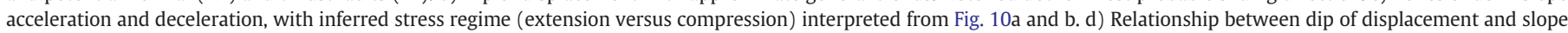

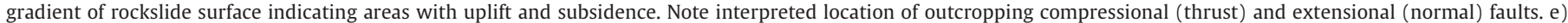

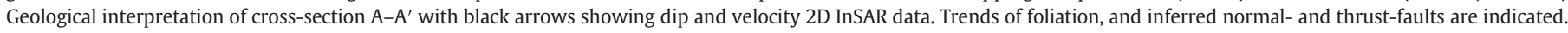
Note red dot and arrow for most probable sliding direction.

from the toe area to back scarp is $\sim 26^{\circ}$. The back scarp itself dips $30-40^{\circ}$ towards NW and is bounded by steep to sub-vertical cross/transverse scarps (Fig. 12). The internal morphology of the rockslide varies, from steep scarps to moderately dipping terraces and lobate landforms.

The active part of the rockslide is well delimited from the surroundings both in the 2D InSAR combined velocity data (Fig. 13a) and dip of displacement (Fig. 13b). Calculated velocities vary spatially between 0 and $100 \mathrm{~mm} / \mathrm{yr}$ in most of the deforming area, with a maximum of $\sim 200 \mathrm{~mm} / \mathrm{yr}$ in the northern part. In the cross-section B-B', velocities are highest in the middle part (Fig. 13c). Dip of displacement shows a general spatial trend from into the slope in the upper part, parallel to the slope in the middle part and out of the slope in the lower part of the rockslide. In cross-section $\mathrm{B}-\mathrm{B}^{\prime}$, the dip of displacement is getting shallower from the upper limit of the deforming area to the lowermost slide front (Fig. 13d), although, internal variations related to slide scarps do exist.

We interpret the general velocity characteristics and dip of displacement out of the slope in the lower part (below $\sim 750 \mathrm{~m}$ ) of cross-section $\mathrm{B}-\mathrm{B}^{\prime}$ to indicate an overall deceleration linked to internal compressive stresses, and/or rotational movements of blocks (Fig. 13d). Lobes or slide blocks stacked on top of each other could explain the observed internal variations in dip of displacement. By comparing these internal 


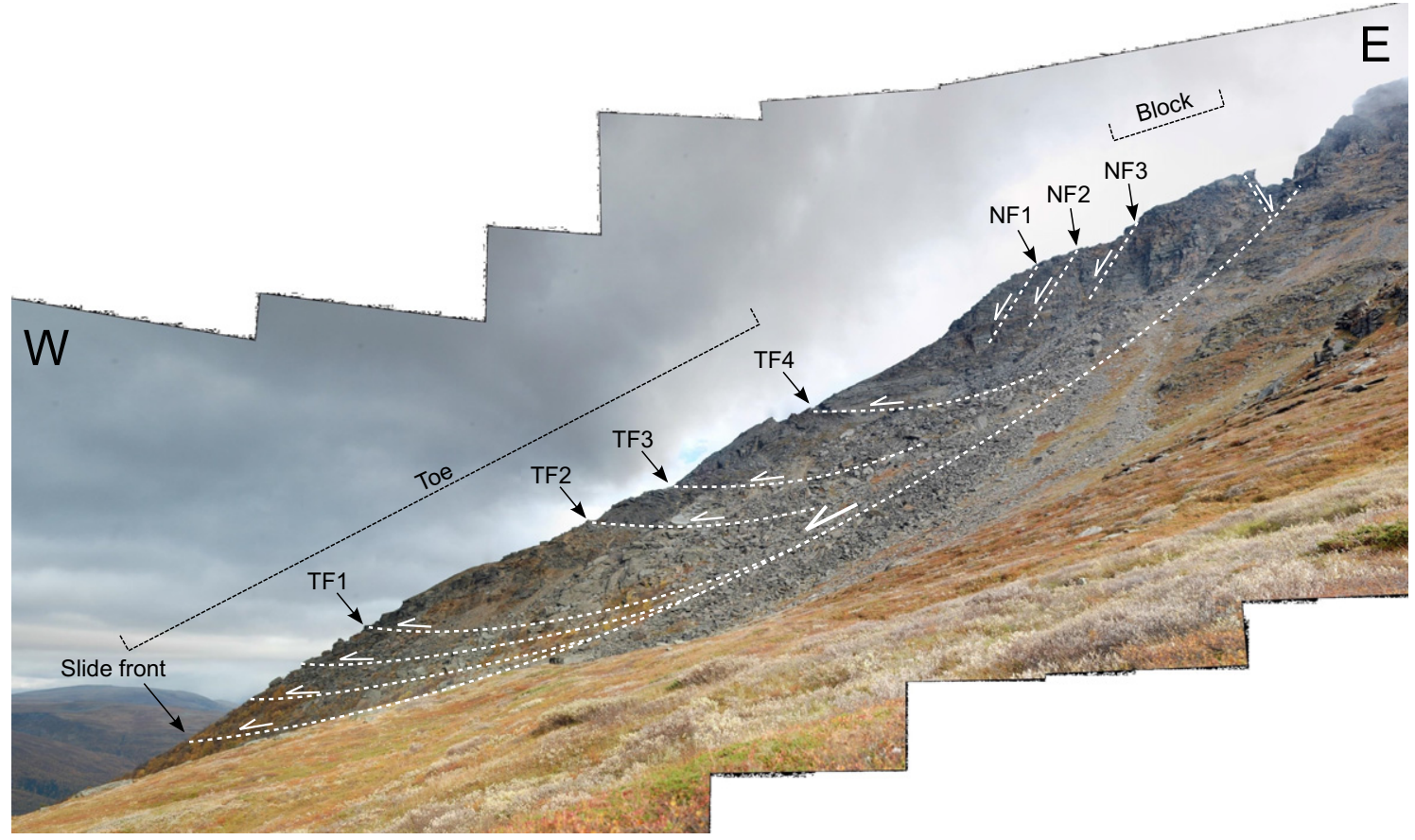

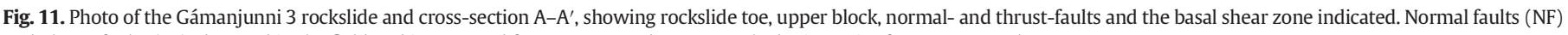
and Thrust faults (TF) observed in the field and interpreted from 2D InSAR data are marked. Viewpoint from $600 \mathrm{~m}$ a.s.l.

variations in surficial morphology (e.g. slide scarps and fronts), we may infer the position of outcropping sliding surfaces or shear zones (Fig. 13e). Judging from the lower velocities in the upper part of the rockslide, basal sliding or deep movement, if active, could be taking place along a discontinuous basal shear zone (Fig. 13e). In this area, the observed dip of displacement is into the surface, and is not easy to explain. We speculate that this may be the result of a favorable orientation of the main foliation in the bedrock, which is rotated inward and may form slide planes within the rockslide. This could also be an effect of the seasonal thaw subsidence, as discussed for the upper part of the Gámanjunni 3 rockslide. More detailed investigations are needed to resolve this.

The lobate landforms in the Njárgavárri rockslide may have been formed by rock glaciers. This is supported by a displacement pattern highly coherent in space (Fig. 13a, b), and thus is an indicator for the presence of stress-transferring ice in the ground (Kääb and Vollmer, 2000). Solifluction processes may also be involved.

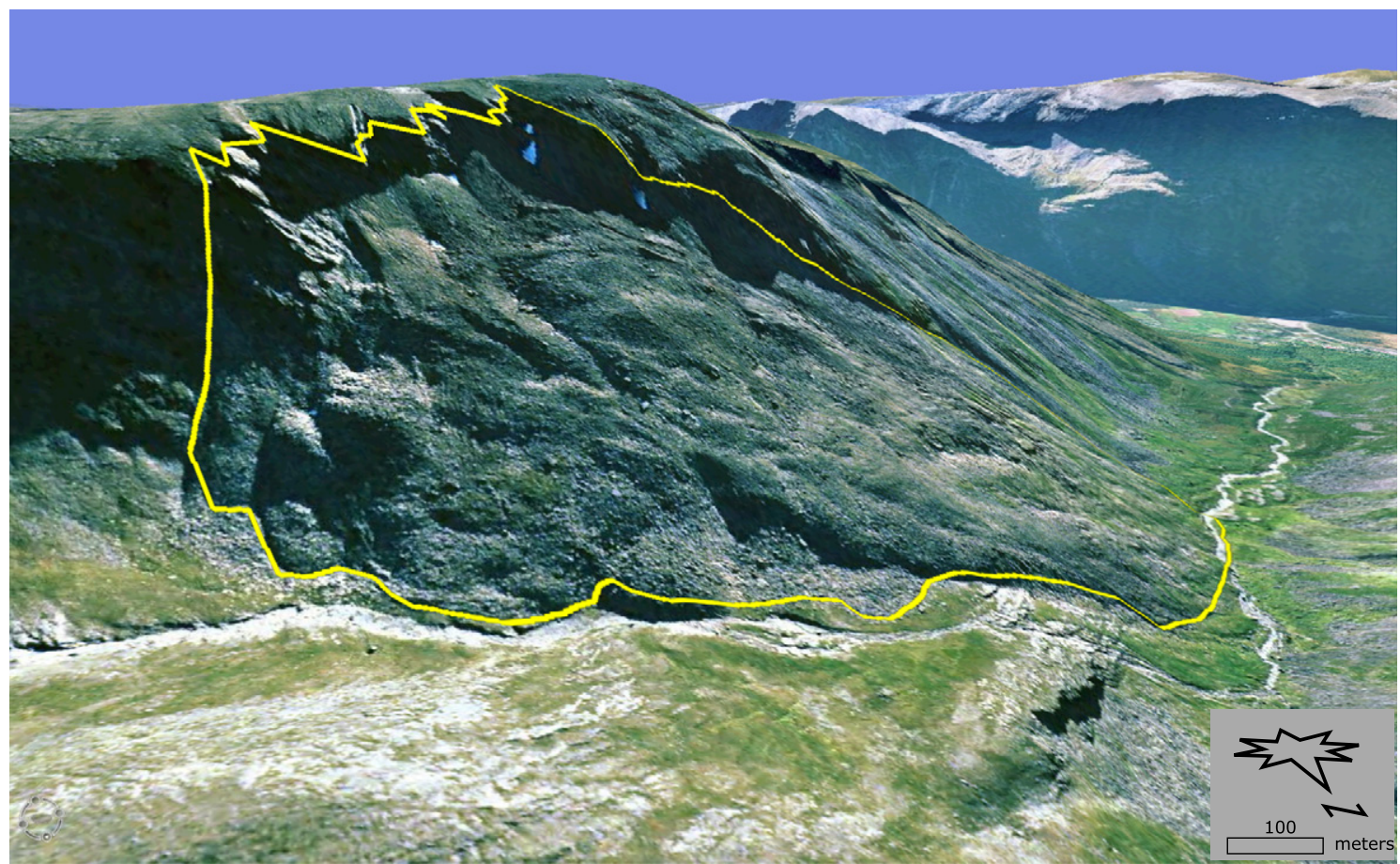

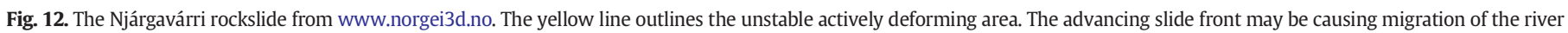
towards the north-west. 

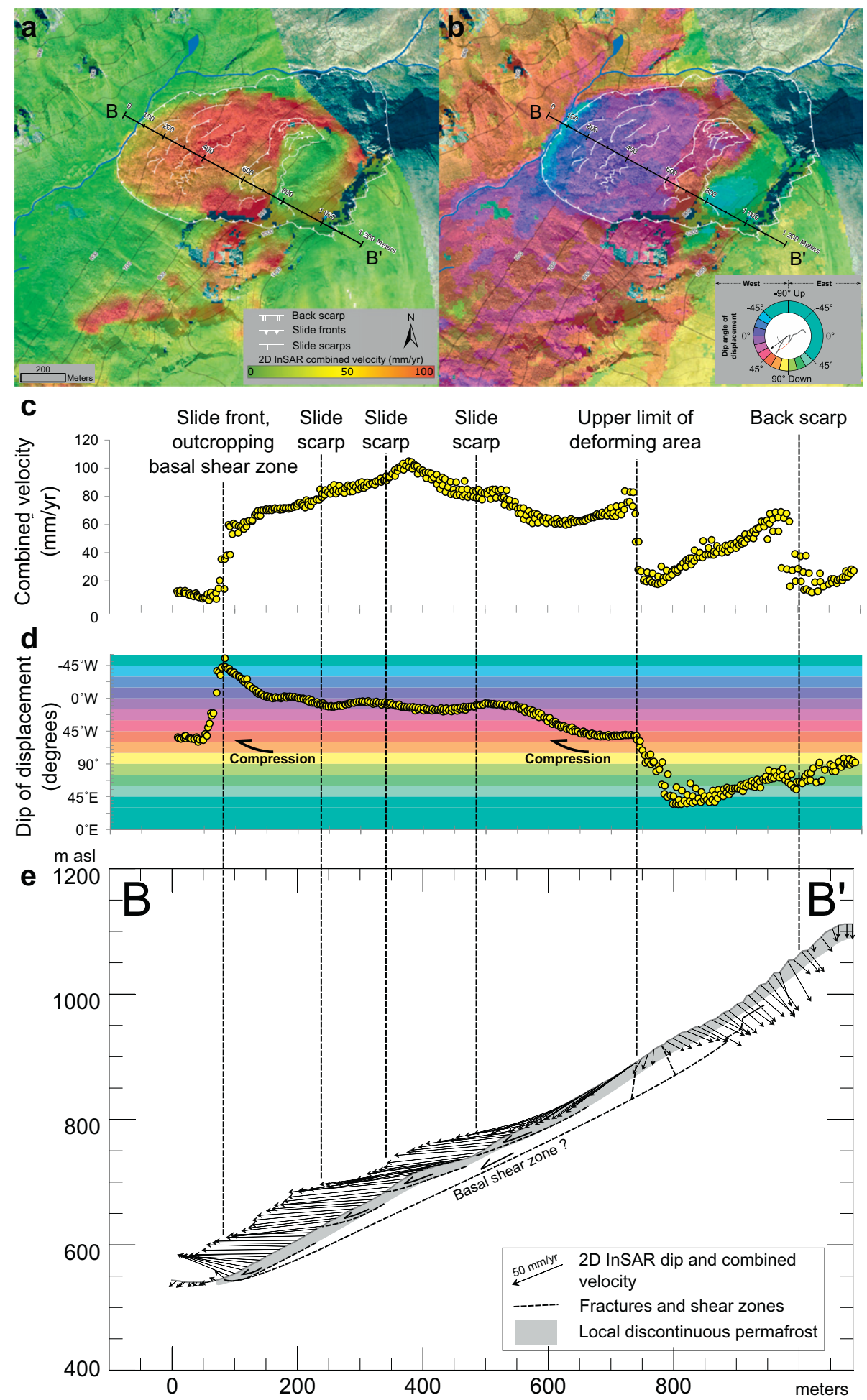

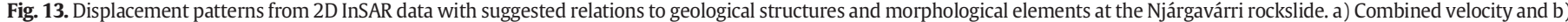

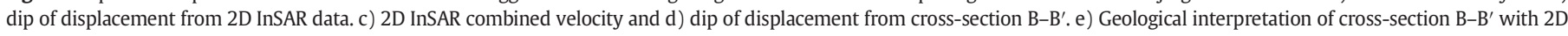
InSAR data marked as arrows.

\subsection{Solifluction landforms on the Nordnes Peninsula}

Solifluction is a slow gravitational down slope movement of water saturated, seasonally thawed materials (Thomas and Goudie, 2000). This process develops on low gradient slopes sufficiently gentle to retain water, and yet sufficiently steep to allow downslope gravitational movement of materials. Freeze-thaw processes move the sediments up orthogonal to the slope gradient when freezing and sub-parallel to the slope gradient when thawing. Thus, solifluction is an ongoing process in many periglacial areas and can produce complex lobeshaped landforms in unconsolidated materials (Matsuoka, 1998, 2001; Harris et al., 2008). 

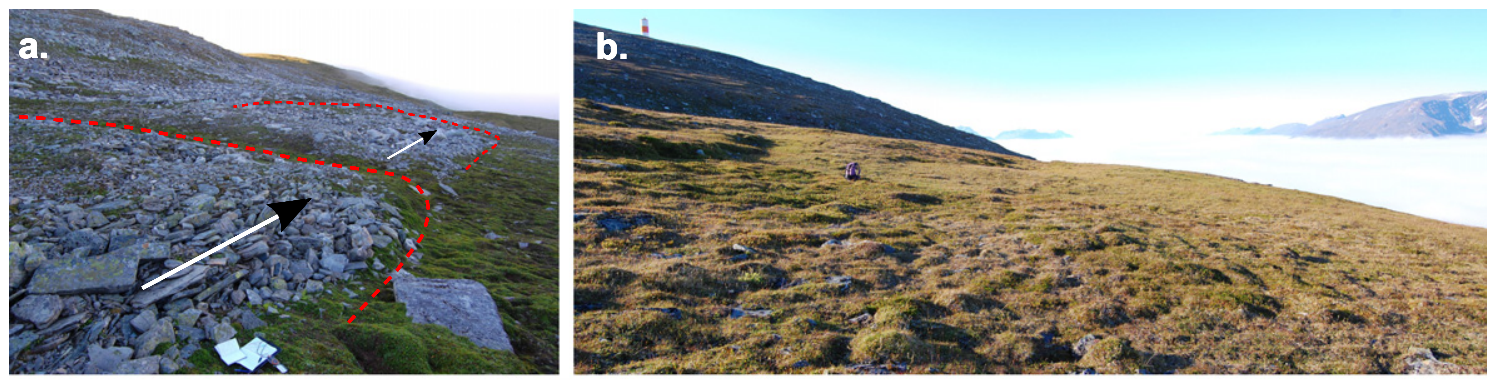

c.

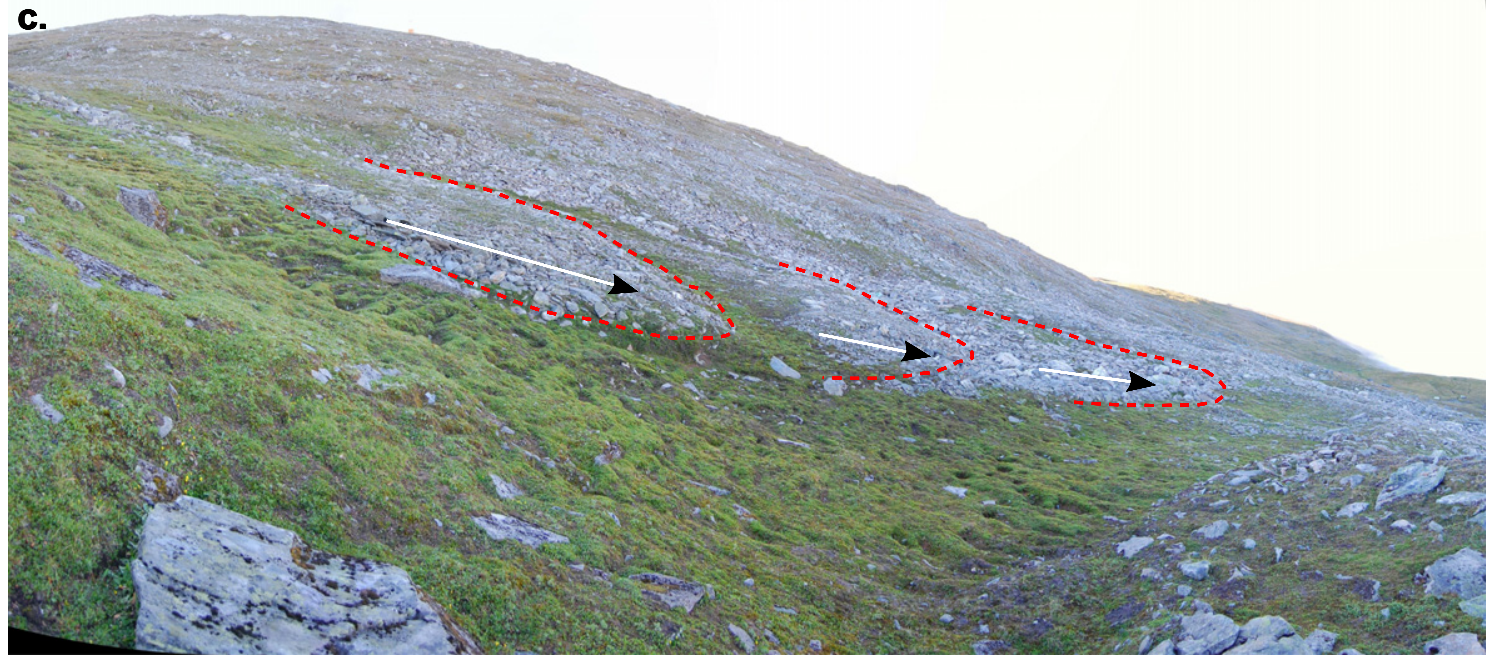

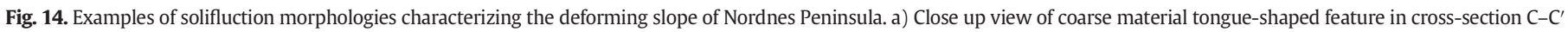

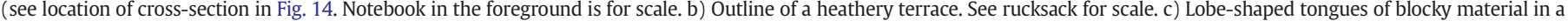
depression in the deforming slope. Arrows indicate movement of the separate tongues.

The solifluction lobes studied at the tip of the Nordnes Peninsula are located in an area covered with glacial till and organic- and boulder-rich material (Fig. 15a, c). They form features ranging in size from decimeters to tens of meters. The slope varies between 0 and $31^{\circ}$. The morphology is characterized by heathery terraces (Fig. 15b) and steeper slopes.

Based on orthophotos and field mapping, we estimate the general displacement direction for the tongue-shaped features to be towards $\mathrm{N}$-E. The cross-section $\mathrm{C}^{-\mathrm{C}^{\prime}}$ is $1200 \mathrm{~m}$ long, located between $\sim 500 \mathrm{~m}$ and $800 \mathrm{~m}$ a.s.l. (Fig. 15a), and is parallel to a depression (gully) in the terrain. In the center of the depression, both coarse- and fine-grained tongue-shaped features are repeated in sets down the fall line. The cross-section D-D' is located in an area with high density of solifluction landforms.

2D InSAR data in both cross-sections reveal high vertical velocity components resulting in steep dip of displacement into the slope (Fig. $15 \mathrm{c}$, f). In cross-section $\mathrm{C}-\mathrm{C}^{\prime}$ we notice an increase in velocity and steeper dip of displacement connected to the more gentle terraces (marked with yellow brackets and columns in Fig. 15a, b, c). We think that drainage from higher ground and consequent accumulation of water in terraces result in more moist conditions. Due to subsidence in thawing sediments in spring and summer, water saturated ground will settle more than dryer areas, explaining the steeper dip of displacement and higher velocities on the terraces. As discussed for the Gámanjunni 3 and Njárgavárri rockslide, we suspect that the 2D InSAR data capture more of the thawing than the freezing part of the seasonal displacement.

In cross-section D- $\mathrm{D}^{\prime}$ the 2D InSAR horizontal component shows variation, with peak values up to $\sim 7 \mathrm{~mm} / \mathrm{yr}$ towards the east. Areas with a high density of solifluction landforms correspond well to areas with high horizontal velocity, where the most active parts of the landforms are visible as peaks in the horizontal data (Fig. 15e, circled data). These variations are hard to see by only looking at ascending and descending data in the cross-section (Fig. 15e).
The mean dip of displacement for cross-section $C-\mathrm{C}^{\prime}$ is $33^{\circ}$. This is steeper than the mean surface gradient in the cross-section $\left(14^{\circ}\right)$. We expect this subsidence to be related to seasonal thaw processes. This is consistent with studies of solifluction landforms elsewhere, e.g. at Dovrefjell in southern Norway, where displacement patterns show heave/uplift in the autumn and thaw/subsidence in the spring and summer (Harris et al., 2008).

\section{Summarizing discussion and conclusion}

In this study, we have demonstrated that combining surface displacement data from two geometries (2D InSAR) provides a powerful tool for visualizing detailed surface displacement patterns. This is shown using three examples: (1) the Gámanjunni 3 rockslide in Manndalen with internal zones of compression and extension and their relation to underlying thrust- and normal-faults, (2) the Njárgavárri rockslide in Kåfjorddalen susceptible to permafrost creep and/or advancing solifluction lobes; and (3) solifluction landforms at the tip of the Nordnes Peninsula.

Contrary to using InSAR displacement data from ascending and descending satellite orbits separately, the 2D InSAR technique has the advantage that it gives the vertical and horizontal component, dip and combined surface displacement. Furthermore, surface displacement patterns from 2D InSAR data in maps and cross-sections show spatial details related to geological structures and geomorphological elements.

This technique shows promising results when trying to correlate displacement patterns with internal structures of rockslides. We show how areas with spatial variations in dip of displacement, often with subtle variations in surface velocity, may give information about the location of potential gliding surfaces (e.g. faults) at depth. More specifically, we give examples of how variations in such 2D InSAR data are used as a tool to explain velocity changes (downslope acceleration/deceleration) that divide rockslides into different compartments, due to outcropping 

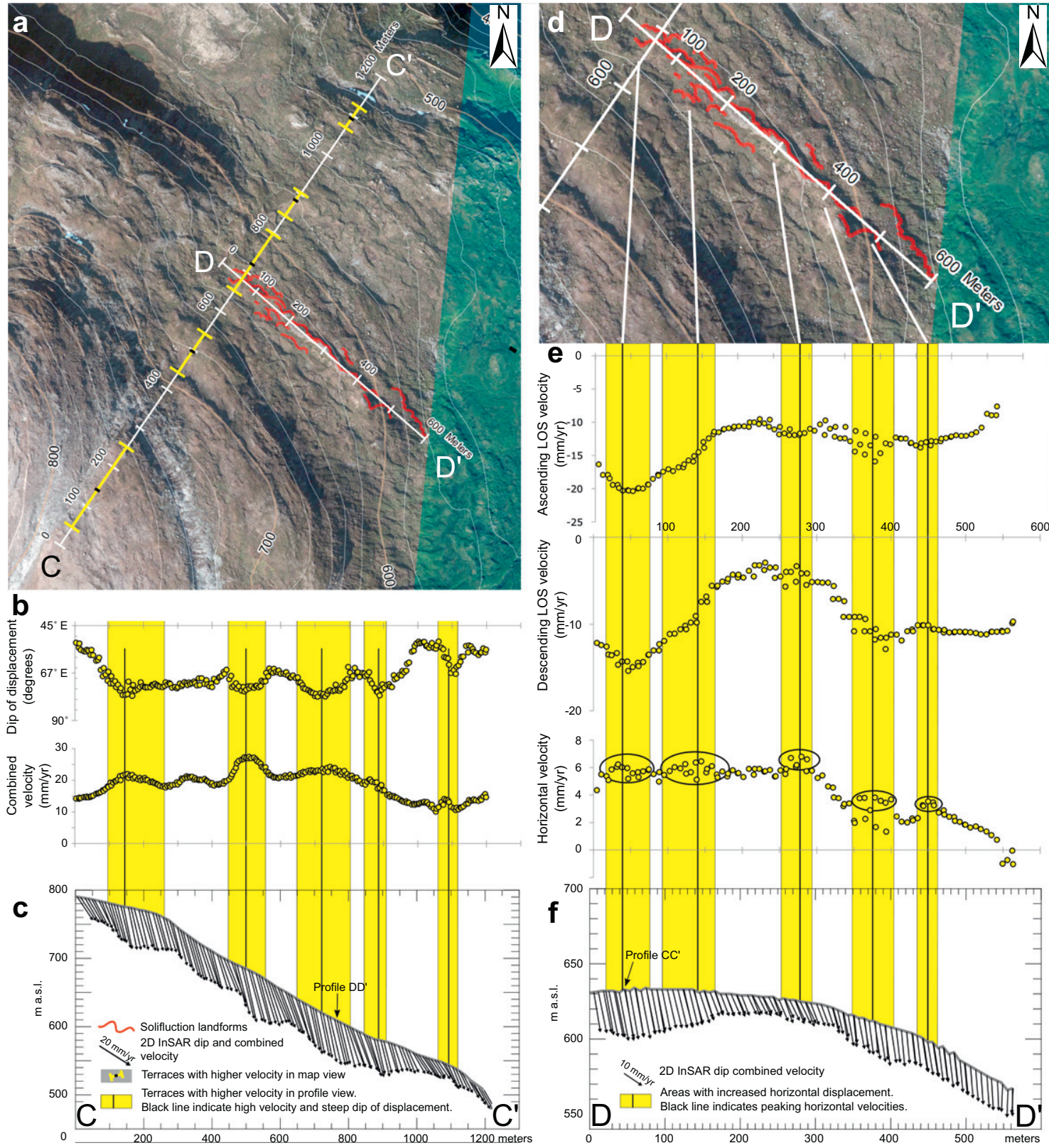

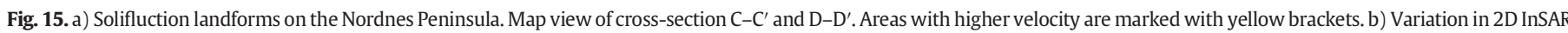

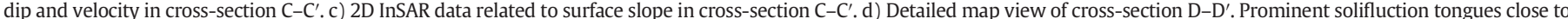

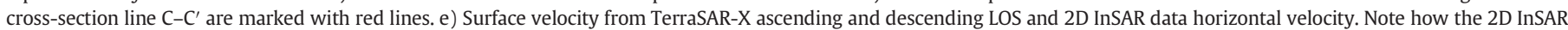

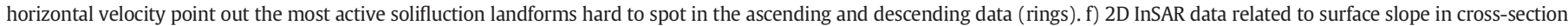
D-D'. Vertical exaggeration for both surfaces slopes are 2 .

thrust- and normal-faults indicating varying stress conditions (compression/extension).

However, the technique has little sensitivity to displacement orthogonal to the LOS plane. For the TerraSAR-X datasets used in this study, surface processes having a large horizontal deformation component in the $\mathrm{N}-\mathrm{S}$ direction will therefore have too steep a dip and underestimated velocity. Because the input datasets are referenced to a common point, a-priori knowledge of velocity at this point is important. In addition, change in vegetation or snow coverage and geometrical effects such as layover and shadow in either of the input datasets, will limit the extent of the produced 2D InSAR data.

2D InSAR makes it possible to postulate overall extension in the upper part and compression in the lower part of rockslides. Furthermore, we found areas with uplift and subsidence by comparing 2D InSAR data to slope gradients. Moreover, we identify the displacement patterns of individual rockslide blocks and their relation to neighbor blocks along outcropping thrust- or normal-fault. The method is also capable of studying velocity variations and degree of activity in solifluction landforms as shown from the Nordnes Peninsula.

2D InSAR data measure the total surface displacement with a velocity component in the LOS-plane (deep movement along basal shear zones and faults; surface movement related to seasonal thawing and permafrost creep). To be able to give exact estimates differentiating between deep and surface movement, a combination of in-situ instrumentations, detailed mapping of surficial deposits, landforms and geological structures together with approaches for quantifying seasonal displacement (freeze/thaw) as presented by Liu et al. (2010); Liu et al. (2012), is needed.

When interpreting 2D InSAR data for sites having varied topography, the user does not, to the same extent as with the single LOS InSAR 
datasets, have to consider the sensors' LOS and how much of the surface displacement component that is possible to measure. Instead, the combination of data from different geometries captured with different LOS supplement each other, increasing the sensitivity to displacement and reducing the complexity related to interpretation of InSAR data.

As with all InSAR studies, the sensors' wavelength and the interferograms' temporal baseline, control the range of velocities that can be measured. In this study we use short (55 day) temporal baseline interferograms from TerraSAR-X data spanning June until October in an alpine subarctic study area with seasonal displacement related to freeze-thaw. By selecting interferograms from the snow-free season, the calculated 2D InSAR data are expected to contain a larger component from thaw than freeze, and adjacent overestimated 2D InSAR mean yearly vertical velocity and steeper dip of displacement values. However, we expect this effect to be most active in the colder upper parts of the study sites. By comparing 2D InSAR data to GNSS data from six GNSS stations at the Jettan rockslide, we find good agreement between the horizontal and combined mean yearly velocity. There is more deviation, but still acceptable agreement, between the vertical component and dip of direction. Standard deviation in the InSAR input data (ascending and descending satellite orbit) and GNSS data is small, $<2.7$ and $<0.53 \mathrm{~mm} / \mathrm{yr}$, respectively. Therefore, we explain the differences between 2D InSAR and GNSS data as being due to the different nature of the measuring techniques (point vs. area) in an area having a complex displacement pattern.

In this study, we have combined two satellite-based datasets producing 2D InSAR, but it is also possible to combine any two InSAR datasets (satellite- or ground based) as long as the LOS vectors differ. Mapping and monitoring of displacement related to landslides/ rockslides, dams, embankments or subsidence from groundwater or oil/gas exploration, are examples of future applications for this method. Future studies should be focused on space/time behavior of displacement phenomena and processes in unstable slope areas by using the 2D InSAR technique on specific time-series data. The technique could also be used in categorizing different slope processes together with their driving and controlling factors.

\section{Acknowledgements}

This research was supported, as part of a PhD program by, Troms County Council, project number 217720 and grant number RDA12/ 165. TerraSAR-X satellite data was provided through the German Aerospace Centre (DLR) TerraSAR-X AO projects \#GEO0565 and GEO0764. We are grateful to the two anonymous reviewers for constructive comments and suggestions. We thank Lars Harald Blikra (NVE), Martina Böhme (NGU) and Markus Eckerstorfer (Norut) for their comments on an earlier version of the manuscript. GNSS data originate from NVE. Thanks to the people at NVE in Manndalen for help with logistics and accommodation during fieldwork. We thank NGU for helping out with logistics during fieldwork, and for sharing DEM and orthophoto from the Gámanjunni 3 rockslide.

\section{References}

Bauer, A., Paar, G., Kaufmann, V., 2003. Terrestrial Laser Scanning for Rock Glacier Monitoring. Proc Eight International Conference on Permafrost Zurich, pp. 55-60.

Berardino, P., Costantini, M., Franceschetti, G., Iodice, A., Pietranera, L., Rizzo, V., 2003. Use of differential SAR interferometry in monitoring and modelling large slope instability at Maratea (Basilicata, Italy). Eng. Geol. 68:31-51. http://dx.doi.org/10.1016/S00137952(02)00197-7.

Blikra, L.H., Henderson, I., Nordvik, T., 2009. Faren for fjellskred fra Nordnesfjellet i Lyngenfjorden, Troms. NGU Rapport 2009.026, p. 29 (in Norwegian).

Blikra, L.H., Christiansen, H.H., 2014. A field-based model of permafrost-controlled rockslide deformation in northern Norway. Geomorphology 208:34-49. http://dx doi.org/10.1016/j.geomorph.2013.11.014.

Blikra, L.H., Christiansen, H., Kristensen, L., Lovisolo, M., 2015. Characterization, geometry, temporal evolution and controlling mechanisms of the Jettan Rock-Slide, Norther Norway. In: Lollino, G., Giordan, D., Crosta, G.B., Corominas, J., Azzam, R., Wasowski,
J., Sciarra, N. (Eds.), Engineering Geology for Society and Territory vol. 2. Springer International Publishing, pp. 273-278.

Bos, M.S., Fernandes, R.M.S., Williams, S.D.P., Bastos, L., 2008. Fast error analysis of continuous GPS observations. J. Geod. 82:157-166. http://dx.doi.org/10.1007/s00190-0070165-X.

Braathen, A., Blikra, L.H., Berg, S., Karlsen, F., 2004. Rock-slope failures in Norway; type, geometry, deformation mechanisms and stability. Nor. J. Geol. 84, 67-87.

Bunkholt, H., Otterå, S., Yugsi Molina, F.X., Hermanns, R.L., Dehls, J., Osmundsen, P.T., Redfield, T., Eiken, T., Böhme, M., 2013a. Undersøkelser av ustabile fjellpartier i Troms - status og planer etter feltarbeid 2011 og 2012. Rapport nr.: 2013.021, p. 110.

Bunkholt, H., Redfield, T., Osmundsen, P.T., Oppikofer, T., Hermanns, R.L., Dehls, J., 2013b. The role of inherited structures in deep seated slope failures in Kåfjorden, Norway. In: Margottini, C., Canuti, P., Sassa, K. (Eds.), Landslide Science and Practice. Springer, Berlin Heidelberg, pp. 265-271.

Böhme, M., Bunkholt, H., Dehls, J.F., Hermanns, R.L., Oppikofer, T., Eriksen, H.Ø., Lauknes, T.R., Eiken, T., Kristensen, L., 2016. Using multiple displacement data to understand the deformation mechanism of the unstable rock slope Gamanjunni 3, northern Norway. 12th International Symposium on Landslides (ISL 2016), 12-19 June 2016, Napoli, Italy.

Cavalié, O., Doin, M.P., Lasserre, C., Briole, P., 2007. Ground motion measurement in the Lake Mead area, Nevada, by differential synthetic aperture radar interferometry time series analysis: probing the lithosphere rheological structure. J. Geophys. Res. Solid Earth 112:18. http://dx.doi.org/10.1029/2006JB004344.

Chaussard, E., Wdowinski, S., Cabral-Cano, E., Amelung, F., 2014. Land subsidence in central Mexico detected by ALOS InSAR time-series. Remote Sens. Environ. 140:94-106. http://dx.doi.org/10.1016/j.rse.2013.08.038.

Chen, C.W., Zebker, H.A., 2001. Two-dimensional phase unwrapping with statistical models for nonlinear optimization. Geoscience and Remote Sensing Symposium, 2000. Proceedings. IGARSS 2000. IEEE 2000 International, pp. 3213-3215.

Eckerstorfer, M., Eriksen, H.Ø., Christiansen, H.H., Lauknes, T.R., Rouyet, L., Blikra, L.H. Comparing geomorphological field and InSAR mapping of the periglacial landscape at Nordnesfjellet, Northern Norway. Earth Surf. Process. Landf. 41, (submitted).

Emardson, T.R., Simons, M., Webb, F.H., 2003. Neutral atmospheric delay in interferometric synthetic aperture radar applications: statistical description and mitigation. J. Geophys. Res. Solid Earth 108 (n/a-n/a). 10.1029/2002JB001781.

Erten, E., Reigber, A., Hellwich, O., 2010. Generation of three-dimensional deformation maps from InSAR data using spectral diversity techniques. ISPRS J. Photogramm. Remote Sens. 65:388-394. http://dx.doi.org/10.1016/j.isprsjprs.2010.04.005.

Fialko, Y., Simons, M., Agnew, D., 2001. The complete (3-D) surface displacement field in the epicentral area of the 1999 MW7.1 Hector Mine earthquake, California, from space geodetic observations. Geophys. Res. Lett. 28:3063-3066. http://dx.doi.org/ 10.1029/2001GL013174.

Fialko, Y., Sandwell, D., Simons, M., Rosen, P., 2005. Three-dimensional deformation caused by the Bam, Iran, earthquake and the origin of shallow slip deficit. Nature 435:295-299. http://dx.doi.org/10.1038/nature03425.

Fujiwara, S., Nishimura, T., Murakami, M., Nakagawa, H., Tobita, M., Rosen, P.A., 2000. 2.5D surface deformation of M6.1 earthquake near Mt Iwate detected by SAR interferometry. Geophys. Res. Lett. 27:2049-2052. http://dx.doi.org/10.1029/1999gl011291.

Funning, G.J., Parsons, B., Wright, T.J., Jackson, J.A., Fielding, E.J., 2005. Surface displacements and source parameters of the 2003 Bam (Iran) earthquake from Envisat advanced synthetic aperture radar imagery. J. Geophys. Res. Solid Earth 110:23. http://dx.doi.org/10.1029/2004JB003338.

Gabriel, A.K., Goldstein, R.M., Zebker, H.A., 1989. Mapping small elevation changes over large areas: differential radar interferometry. J. Geophys. Res. Solid Earth 94: 9183-9191. http://dx.doi.org/10.1029/JB094iB07p09183.

Gernhardt, S., Bamler, R., 2012. Deformation monitoring of single buildings using meterresolution SAR data in PSI. ISPRS J. Photogramm. Remote Sens. 73:68-79. http://dx. doi.org/10.1016/j.isprsjprs.2012.06.009.

Goldstein, R.M., Werner, C.L., 1998. Radar interferogram filtering for geophysical applications. Geophys. Res. Lett. 25:4035-4038. http://dx.doi.org/10.1029/1998GL900033.

González, P., Fernández, J., Camacho, A., 2009. Coseismic three-dimensional displacements determined using SAR data: theory and an application test. Pure Appl. Geophys. 166:1403-1424. http://dx.doi.org/10.1007/s00024-009-0500-7.

Gourmelen, N., Amelung, F. Casu, F, Manzo, M., Lanari, R, 2007. Mining-related ground deformation in Crescent Valley, Nevada: implications for sparse GPS networks. Geophys. Res. Lett. 34, L09309. http://dx.doi.org/10.1029/2007GL029427.

Harris, C., Kern-Luetschg, M., Smith, F., Isaksen, K., 2008. Solifluction processes in an area of seasonal ground freezing, Dovrefjell, Norway. Permafr. Periglac. Process. 19:31-47. http://dx.doi.org/10.1002/ppp.609.

Henderson, I.H.C., Osmundsen, P.T., Redfield, T., 2008. ROS Fjellskred i Troms: Statusrapport 2007. NGU report 2008.025, p. 38 (in Norwegian).

Henderson, I.H.C., Lauknes, T.R., Osmundsen, P.T., Dehls, J., Larsen, Y., Redfield, T.F., 2011. A structural, geomorphological and InSAR study of an active rock slope failure development. Geol. Soc. Lond., Spec. Publ. 351:185-199. http://dx.doi.org/10.1144/sp351.10.

Hermanns, R.L. Blikra, L.H., Anda, E., Saintot, A., Dahle, H., Oppikofer, T., Fischer, L, Bunkholt, H., Böhme, M., Dehls, J.F., Lauknes, T.R., Redfield, T.F., Osmundsen, P.T., Eiken, T., 2013. Systematic mapping of large unstable rock slopes in Norway. In: Margottini, C., Canuti, P., Sassa, K. (Eds.), Landslide Science and Practice. Springer, Berlin Heidelberg, pp. 29-34

Hilley, G.E., Burgmann, R., Ferretti, A., Novali, F., Rocca, F., 2004. Dynamics of slow-moving landslides from permanent scatterer analysis. Science 304:1952-1955. http://dx.doi. org/10.1126/science.1098821.

Hjort, J., Ujanen, J., Parviainen, M., Tolgensbakk, J., Etzelmüller, B., 2014. Transferability of geomorphological distribution models: evaluation using solifluction features in subarctic and Arctic regions. Geomorphology 204:165-176. http://dx.doi.org/10.1016/j. geomorph.2013.08.002. 
Hu, J., Li, Z.W., Ding, X.L., Zhu, J.J., Zhang, L., Sun, Q., 2014. Resolving three-dimensional surface displacements from InSAR measurements: a review. Earth Sci. Rev. 133: 1-17. http://dx.doi.org/10.1016/j.earscirev.2014.02.005.

Joughin, I.R., Kwok, R., Fahnestock, M.A., 1998. Interferometric estimation of three-dimensional ice-flow using ascending and descending passes. IEEE Trans. Geosci. Remote Sens. 36:25-37. http://dx.doi.org/10.1109/36.655315.

Kaufmann, V., 1998. Deformation Analysis of the Doesen Rock Glacier (Austria). Proceedings of the Seventh International Permafrost Conference. Collection Nordicana, Centre de'tudes nordiques, Universite' Laval, Yellowknife, Canada, pp. 551-556.

Kierulf, H.P., Steffen, H., Simpson, M.J.R., Lidberg, M., Wu, P., Wang, H., 2014. A GPS velocity field for Fennoscandia and a consistent comparison to glacial isostatic adjustment models. J. Geophys. Res. Solid Earth 119:6613-6629. http://dx.doi.org/10.1002/ 2013JB010889.

Konrad, S.K., Humphrey, N.F., Steig, E.J., Clark, D.H., Potter, N., Pfeffer, W.T., 1999. Rock glacier dynamics and paleoclimatic implications. Geology 27:1131-1134. http://dx.doi. org/10.1130/0091-7613(1999)027<1131:rgdapi>2.3.co;2.

Krainer, K., Mostler, W., 2000. Reichenkar rock glacier: a glacier derived debris-ice system in the western Stubai Alps, Austria. Permafr. Periglac. Process. 11:267-275. http://dx. doi.org/10.1002/1099-1530(200007/09)11:3<267::AID-PPP350>3.0.CO;2-E.

Krainer, K., He, X., 2006. Flow velocities of active rock glaciers in the Austrian Alps. Geogr. Ann. Ser. A Phys. Geogr. 88:267-280. http://dx.doi.org/10.1111/j.0435-3676.2006. 00300.x.

Kääb, A., Vollmer, M., 2000. Surface geometry, thickness changes and flow fields on creeping mountain permafrost: automatic extraction by digital image analysis. Permafr. Periglac. Process. 11:315-326. http://dx.doi.org/10.1002/1099-1530(200012)11: 4<315::AID-PPP365>3.0.CO;2-J.

Kääb, A., 2002. Monitoring high-mountain terrain deformation from repeated air- and spaceborne optical data: examples using digital aerial imagery and ASTER data. ISPRS J. Photogramm. Remote Sens. 57:39-52. http://dx.doi.org/10.1016/S09242716(02)00114-4.

Langley, R.B., 1999. Dilution of precision. GPS World, pp. 52-59.

Larsen, Y., Engen, G., Lauknes, T.R., Malnes, E., Høgda, K.A., 2005. A Generic Differential Interferometric SAR Processing System, with Applications to Land Subsidence and Snow-Water Equivalent Retrieval. Proc. ESA Fringe 2005, ESA ESRIN, Frascati, Italy, November 28-December 2 (unpublished).

Lauknes, T.R., Shanker, A.P., Dehls, J.F., Zebker, H.A., Henderson, I.H.C., Larsen, Y., 2010. Detailed rockslide mapping in northern Norway with small baseline and persistent scatterer interferometric SAR time series methods. Remote Sens. Environ. 114: 2097-2109. http://dx.doi.org/10.1016/j.rse.2010.04.015.

Lilleøren, K.S., Etzelmüller, B., 2011. A regional inventory of rock glaciers and ice-cored moraines in Norway. Geogr. Ann. 93:175-191. http://dx.doi.org/10.111/j.14680459.2011.00430.x.

Liu, L., Zhang, T., Wahr, J., 2010. InSAR measurements of surface deformation over permafrost on the North Slope of Alaska. J. Geophys. Res. 115. http://dx.doi.org/10.1029/ 2009jf001547.

Liu, L., Schaefer, K., Zhang, T., Wahr, J., 2012. Estimating 1992-2000 average active layer thickness on the Alaskan North Slope from remotely sensed surface subsidence. J. Geophys. Res. 117:14. http://dx.doi.org/10.1029/2011jf002041.
Liu, L., Millar, C.I., Westfall, R.D., Zebker, H.A., 2013. Surface motion of active rock glaciers in the Sierra Nevada, California, USA: inventory and a case study using InSAR. Cryosphere 7:1109-1119. http://dx.doi.org/10.5194/tc-7-1109-2013.

Lyons, S., Sandwell, D., 2003. Fault creep along the southern San Andreas from interferometric synthetic aperture radar, permanent scatterers, and stacking. J. Geophys. Res. Solid Earth 108 n/a-n/a. 10.1029/2002JB001831.

Manzo, M., Ricciardi, G.P., Casu, F., Ventura, G., Zeni, G., Borgström, S., Berardino, P., De Gaudio, C., Lanari, R., 2006. Surface deformation analysis in the Ischia Island (Italy) based on spaceborne radar interferometry. J. Volcanol. Geotherm. Res. 151: 399-416. http://dx.doi.org/10.1016/j.jvolgeores.2005.09.010.

Massonnet, D., Rossi, M., Carmona, C., Adragna, F., Peltzer, G., Feigl, K., Rabaute, T., 1993. The displacement field of the landers earthquake mapped by radar interferometry. Nature 356:138-142. http://dx.doi.org/10.1038/364138a0.

Massonnet, D., Briole, P., Arnaud, A., 1995. Deflation of Mount Etna monitored by spaceborne radar interferometry. Nature 375:567-570. http://dx.doi.org/10.1038/ $375567 a 0$.

Massonnet, D., Feigl, K.L., 1998. Radar interferometry and its application to changes in the Earth's surface. Rev. Geophys. 36:441-500. http://dx.doi.org/10.1029/97RG03139.

Matsuoka, N., 1998. The relationship between frost heave and downslope soil movement: field measurements in the Japanese Alps. Permafr. Periglac. Process. 9:121-133. http://dx.doi.org/10.1002/(SICI)1099-1530(199804/06)9:2<121::AID-PPP281>3.0. $\mathrm{CO} ; 2-\mathrm{C}$.

Matsuoka, N., 2001. Solifluction rates, processes and landforms: a global review. Earth Sci. Rev. 55:107-134. http://dx.doi.org/10.1016/S0012-8252(01)00057-5.

Nordvik, T., Blikra, L.H., Nyrnes, E., Derron, M.H., 2010. Statistical analysis of seasonal displacements at the Nordnes rockslide, northern Norway. Eng. Geol. 114:228-237. http://dx.doi.org/10.1016/j.enggeo.2010.04.019.

Peltzer, G., Crampé, F., Hensley, S., Rosen, P., 2001. Transient strain accumulation and fault interaction in the Eastern California shear zone. Geology 29:975-978. http://dx.doi. org/10.1130/0091-7613(2001)029<0975:tsaafi >2.0.co;2.

Rucci, A., Ferretti, A., Novali, F., Tamburini, A., Vasco, D.W., 2011. Multi-geometry SAR Interferometry for $\mathrm{CO}_{2}$ sequestration monitoring. SEG Technical Program Expanded Abstracts 2011, pp. 2054-2058.

Skrede, I., 2013. Jettan, Nordnesfjellet, Kåfjord, Troms-indre geomtri og struktur, kinematikk og styrande faktorar av eit ustabilt fjellparti, basert på strukturellanalyse geomorfologi og overvakingsdata, Thesis. UiT-The Arctic University of Norway, Tromsø, Norway:p. 176 ((in Norwegian), http://hdl.handle.net/10037/5622).

Thomas, D.S.G., Goudie, A., 2000. The Dictionary of Physical Geography.

Williams, P.S.D., 2003. The effect of coloured noise on the uncertainties of rates estimated from geodetic time series. J. Geod. 76:483-494. http://dx.doi.org/10.1007/s00190002-0283-4

Wright, T.J., Parsons, B.E., Lu, Z., 2004. Toward mapping surface deformation in three dimensions using InSAR. Geophys. Res. Lett. 31, L01607. http://dx.doi.org/10.1029/ 2003 GL018827. 